\title{
Grand challenges and entrepreneurship: Emerging issues, research streams, and theoretical landscape
}

\author{
Francesca Ricciardi ${ }^{1}$. Cecilia Rossignoli ${ }^{2}$ - Alessandro Zardini ${ }^{2}$
}

Published online: 7 October 2021

(c) The Author(s) 2021

\begin{abstract}
This study discusses how the role of entrepreneurship in addressing the so-called "grand challenges" (e.g., poverty, inequality, pollution, climate change) is evolving and could further evolve, based on the ongoing conversation in the scholarly community. To develop the discussion, we conducted the following steps: (1) a computer-aided semantic analysis; (2) an analysis of the evolution of literature streams; and (3) a network analysis of advocated theories and approaches. All three analyses were based on a selection of 358 publications retrieved via a keyword search and 27 further publications retrieved via an analysis of five recent and relevant special issues published by important scientific journals. Our results show that the call to address grand challenges, particularly after the publication of the United Nations' Sustainable Development Goals (SDGs), is radically transforming entrepreneurship research, with new issues emerging and replacing traditional issues as core to the discipline, marking a rapid and complex dynamics of research stream divergence and convergence. Similarly, the network of theories and approaches advocated by recent agenda-setting articles depicts an emerging theoretical landscape that is highly innovative. This new theoretical landscape revolves around systems thinking and Ostrom's theory of the commons as the two key poles, with the embeddedness, stakeholder, institutional, effectuation, processual, and design-oriented approaches being the cross-fertilizing forces linking these two poles. In the final section, we present the nine articles included in the special issue titled "Grand Challenges and Entrepreneurship: Emerging Issues and Research Streams" and briefly synthesize these in the light of the ongoing evolution of the literature.
\end{abstract}

Keywords SDGs · Grand challenges · Sustainable entrepreneurship · Impact entrepreneurship $\cdot$ Commons $\cdot$ Systemic approach

Francesca Ricciardi

francesca.ricciardi@unito.it

$\triangle$ Alessandro Zardini

alessandro.zardini@univr.it

Extended author information available on the last page of the article 


\section{Introduction}

Grand challenges can be defined as the social and/or environmental challenges that are so formidable and global that they transcend the problem-solving capacities of individual firms, communities, industries, and even governments and nations (Markman et al., 2019). They include challenges such as climate change, pollution, poverty, inequality, disruption of conventional economies due to digitization, and pandemics (George et al., 2016). Grand challenges are also defined as system-level wicked problems, that is, problems that cannot be solved once forever, meaning that each solution that is implemented, even if successful, tends to result in unintended consequences, which, in turn, must then be understood and addressed. For example, solar panels may be very good in decreasing carbon emissions, but their lifecycle and diffusion raises new environmental and employability issues (Ferraro et al., 2015). In fact, grand challenges involve radical uncertainties about the consequences of each decision made to resolve the challenge, and then multiple and conflicting evaluations among stakeholders (Grimes \& Vogus, 2021).

Because of their wicked nature, grand challenges can be addressed only through never-ending, highly distributed experimentation and savvy selection and recombination of possible solutions (Martí, 2018). It is no wonder then that entrepreneurship, as a unique force for multiplying innovation capacities, has been increasingly called into action to address these wicked problems (Foucrier \& Wiek, 2019; Masdeu Yélamos et al., 2019). Many entrepreneurship scholars have framed the role of entrepreneurship in addressing grand challenges within a traditional theoretical view, rooted in classical economics. When considered from this perspective, grand challenges translate into market failures (Dean \& McMullen, 2007) that attract entrepreneurial action because transforming market failures into business opportunities is exactly what entrepreneurship is all about in classical economics (Villar \& Miralles, 2019). This is actually an elegant, straightforward, and pleasantly optimistic explanation of the relationship between entrepreneurship and grand challenges.

However, dissatisfaction has grown around this classical view of the entrepreneurship - grand challenges nexus. In fact, the idea that market failures, which by definition are problems resulting from market actors prioritizing rentseeking, should be solved by entrepreneurs, who are classically conceived as market actors that prioritize rent-seeking, seems uncomfortably likely to reinforce vicious cycles in wicked problems. Thus, an alternative idea is gaining traction: that realworld entrepreneurs who effectively contribute to addressing grand challenges actually prioritize something other than mere rent-seeking, and behave differently from what classical economics defines as "rational" market actors (George et al., 2020; Grimes \& Vogus, 2021).

The push to rethink the very foundations of entrepreneurship research and practice has been dramatically boosted by the approval in 2015 of the 17 Sustainable Development Goals (SDGs) by the United Nations (2015). The SDGs were immediately acknowledged by scholars and practitioners alike as the translation of grand 
challenges into concrete objectives to be collectively pursued by 2030 . The business and management scholarly literature has increasingly begun to refer to the SDGs as the new logic that will shape the behaviors of decision makers, entrepreneurs, and managers (Crecente et al., 2021). A sense of urgency has spread among all scholarly communities: the clock is ticking, and unless the rate of progress in achieving the SDGs accelerates dramatically, once unthinkable systemic collapses are now perceived as concretely impending (Apostolopoulos et al., 2018). The pandemic crisis that began in 2020, and the tragic climate events hitting different parts of the planet in 2021, are intensifying this sense of urgency.

There is a lot of work to do. Despite some visionary statements that entrepreneurship is part of the solution, rather than part of the problem (Muñoz \& Cohen, 2018), most real-world entrepreneurial actions still deplete more environmental and social resources than are (re)generated through such actions, thus contributing negatively to the achievement of the SDGs (Venâncio \& Pinto, 2020). Many entrepreneurship scholars are taking responsibility for this, and are striving to develop new views and approaches that will concretely help change the role of entrepreneurship from being the engine of (system-threatening) economic growth to being the engine of sustainable development (Doh et al., 2019). These new views are greatly needed to provide the world of practice with innovative and effective models (Wiklund et al., 2019) in a scenario in which completely new organizational and juridical forms are emerging to respond to grand challenges, for example, B Corporations (Stubbs, 2017).

However, shifting the entrepreneurship research field toward a new view in the face of grand challenges is no easy task. Completely new themes must be identified to catalyze a new generation of scholarly work; the research community must selforganize in new cross-fertilizing streams and substreams; and, perhaps even more importantly, new theories on the actual and expected roles of entrepreneurship in the face of grand challenges must be developed and tested to allow for the accumulation of sound scientific knowledge.

How is the scholarly community responding to this call? What paths are being collectively created for the future of entrepreneurship as a field of research? To address these questions, this study focuses on three specific objectives:

investigation of how the key themes addressed by the literature on entrepreneurship and grand challenges have changed in recent years, particularly after 2015, the year in which the 17 SDGs were approved and made public;

analysis of the evolution of the key research streams that have focused on the role of entrepreneurship in addressing grand challenges;

discovery of the new theoretical landscape as it emerges from the literature addressing the need for new views and new approaches to understand how entrepreneurship does, and could and should contribute to addressing grand challenges.

To pursue these objectives, we conduct the following steps: (1) a computer-aided semantic analysis of a selection publications; (2) a taxonomic analysis of literature streams; and (3) a network analysis of advocated theories and approaches. 
Our results reveal three principal conclusions. First, in recent years, new themes have emerged as key to the entrepreneurship - grand challenges nexus, for example, digitalization and the organizational implications of sustainability-oriented venturing, while themes that were traditionally linked to classical development and business research, such as innovation, have become semantic satellites of the sustainability concept. Second, after a divergent phase, with numerous parallel substreams around green, social, and institutional entrepreneurship, the scholarly community is now making relevant efforts to converge on a new integrated view of entrepreneurship by advancing the new concepts of sustainable and collective entrepreneurship and, somehow more radically, of impact- or purposedriven entrepreneurship. Third, the network of theories and approaches advocated by recent agenda-setting articles depicts an emerging theoretical landscape that is highly innovative. This new theoretical landscape revolves around systems thinking (Meadows, 2009) and Ostrom's theory of the commons (Ostrom, 1990) as the two key theoretical poles, with the social embeddedness, institutional, stakeholder, effectuation, processual, and design-oriented approaches being cross-fertilizing forces linking these two poles (which are strongly complementary and intertwined, e.g. Ostrom, 2009).

We also find widespread dissatisfaction in the recent literature with mainstream approaches, such as the triple bottom line (3BL) (Muñoz et al., 2018) or conventional, firm-centric stakeholder analyses (Lumpkin \& Bacq, 2019). This dissatisfaction revolves around the idea that both $3 \mathrm{BL}$ and traditional stakeholder analyses are too firm-centric and thus fail to grasp the role played by a specific enterprise at the level of the social-ecological system. Institutional approaches are also increasingly emphasized as possibly leading to simplistic views of how entrepreneurship could contribute to addressing grand challenges. In fact, even full compliance with (socially co-created) rules may trigger sustainability-threatening consequences, and when this happens, institutional work and the pursuit of legitimacy are likely insufficient mechanisms to address the wicked nature of grand challenges (Jones et al., 2019).

Several interesting proposals are being advanced in the literature to update and cross-fertilize these mainstream approaches with each other and with systems and commons-oriented thinking, with the aim of overcoming the traditional limitations of these approaches. An overview of 19 recent and particularly interesting articles advancing such proposals is provided in the section dedicated to the new emerging theories and approaches, particularly in the tables complementing that section. We model and discuss this complex and networked emerging theoretical scenario; we argue that it is promising and might, if its potential is fully realized, rise to the challenge of grand challenges.

The results of our three analyses converge to demonstrate that the entrepreneurship field is highly dynamic: a strong urge to change is widely shared in our scholarly community, which is duly responding to this urgent need for change with new, inspiring research streams and a new, highly innovative theoretical landscape.

The International Entrepreneurship and Management Journal has contributed to this lively debate by launching a special issue on the theme "Grand Challenges and Entrepreneurship: Emerging Issues and Research Streams". In the final section, we 
present the nine articles included in this special issue, and briefly synthesize them in light of the ongoing evolution of the literature, as analyzed throughout the article.

\section{Entrepreneurship and grand challenges: New emerging issues and themes}

The first phase of our exploration focuses on how scholarly perceptions are evolving and on which issues and topics are key to understand the role of entrepreneurship in the face of grand challenges. To investigate this evolution, we conducted a text analysis aided by Leximancer software on a basket of 358 scientific articles selected in June 2021. Leximancer provides a powerful Bayesian machine-learning algorithm for deciphering and visualizing complex text data (Campbell et al., 2011) through both conceptual (thematic) and relational (semantic) analyses of text data (Wilden et al., 2016).

The articles were selected via a keyword search on the Scopus database, followed by title and abstract analysis to exclude duplicates and nonrelevant publications. Only journal articles in English were included. The words searched in the title, abstract and keywords were "entrepreneurship" AND "grand challenges" OR "SDG" (54 articles were selected); "sustainable entrepreneurship" AND "literature review" (13 articles were selected); "entrepreneurship" AND "climate change" (60 articles were selected); "entrepreneurship" AND "digital society" (41 articles were selected); "entrepreneurship" AND "food" AND "sustainability" (61 articles were selected); "entrepreneurship" AND "poverty" (73 articles were selected); "entrepreneurship" AND "social inclusion" (56 articles were selected).

Then, we separated the articles into two groups: those published pre-2016, that is, before and during 2015 (the year in which the United Nations SDGs were approved, which boosted the debate on the role of business in the face of grand challenges) and those published post-2015, that is, in and after 2016. Subsequently, Leximancer was used to analyze and compare the conceptual-semantic maps emerging from the two groups of articles. Leximancer represents the words that play the role of core concepts in the analyzed texts as colored circles, possibly overlapping with other circles that represent other associated concepts if recurrent semantic overlapping is present in the text; each circle includes some second-level related concepts.

The results (Figs. 1 and 2) highlight a dramatic change in the landscape of issues and topics that are at the core of the scholarly attention in the literature on the entrepreneurship - grand challenges nexus. After the publication of the SDGs by the United Nations, only a minority of the concepts that were key in the previous years (Fig. 1) remained key in the new semantic landscape (Fig. 2) around entrepreneurship. These are the concepts of change, people, and production. These concepts effectively depict the enduring backbone of the scholarly reflection on the role of entrepreneurship: it is about people that address change (e.g., climate change) by making changes in value production patterns.

Conversely, some "classical" entrepreneurship themes lost traction after 2015, for example, policy, institutional, development, business, enterprise, education, and 


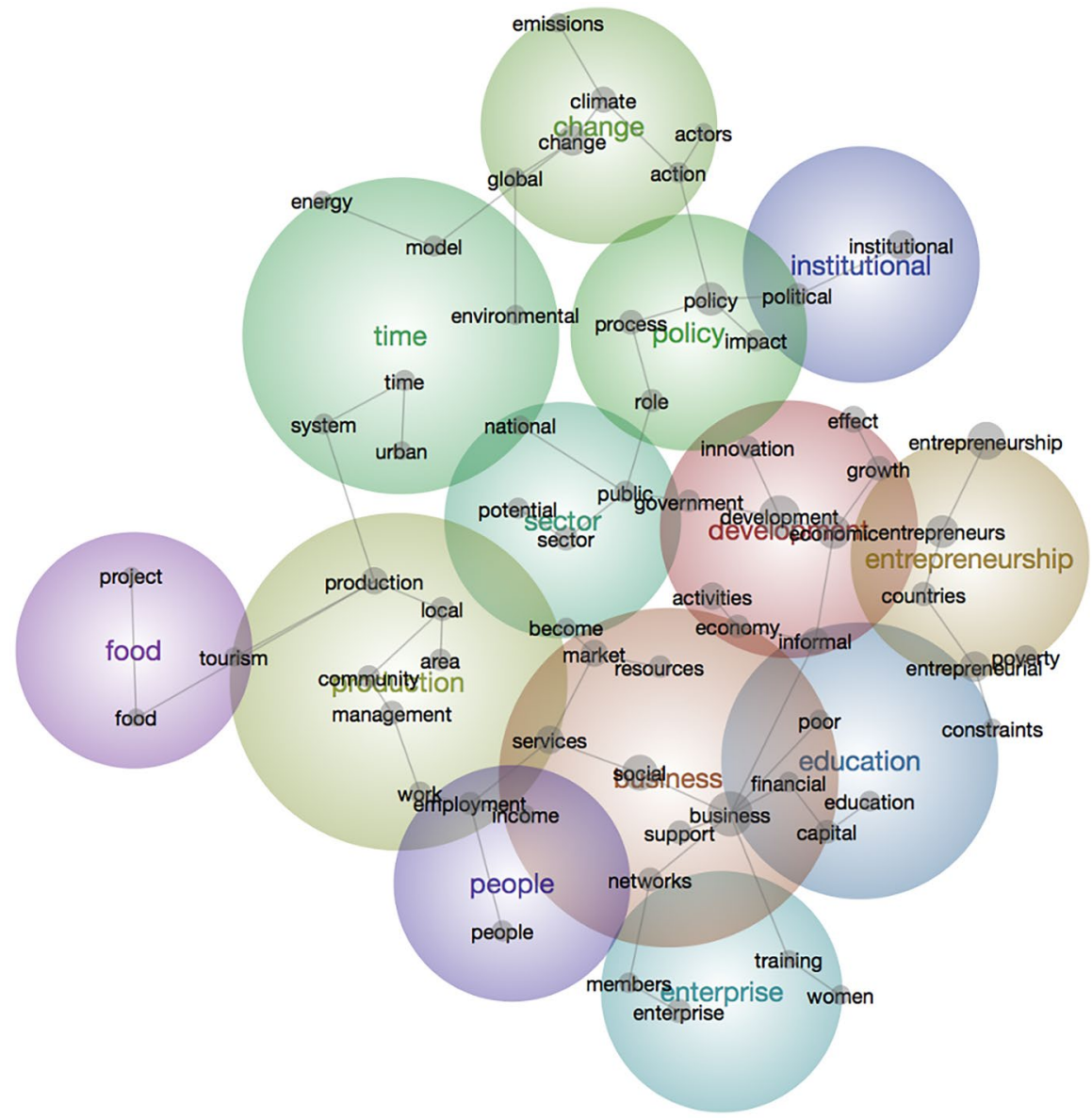

Fig. 1 The semantic map of a selection of scientific literature published before and during 2015 on entrepreneurship and grand challenges (elaboration aided by Leximancer)

some new concepts have emerged forcefully, for example, digital, poverty, social, sustainable. Importantly, as clearly visible in Fig. 2, the concept of sustainable has "incorporated" that of development, which in the previous semantic scenario (Fig. 1) had a major circle in its own right. The concept of innovation, which was also included in the development semantic circle before 2015, has shifted into the sustainable semantic circle in the last years. Also very interestingly, the concept of impact left the policy circle to move into the market circle: this change powerfully highlights that the responsibility of generating impact, which was previously "delegated" (according to classical economics) to policymaking, is today considered a purpose that directly challenges market actors.

In addition, some further emerging themes suggest the growing importance of organizational challenges in the most recent debate on the responsibilities of 


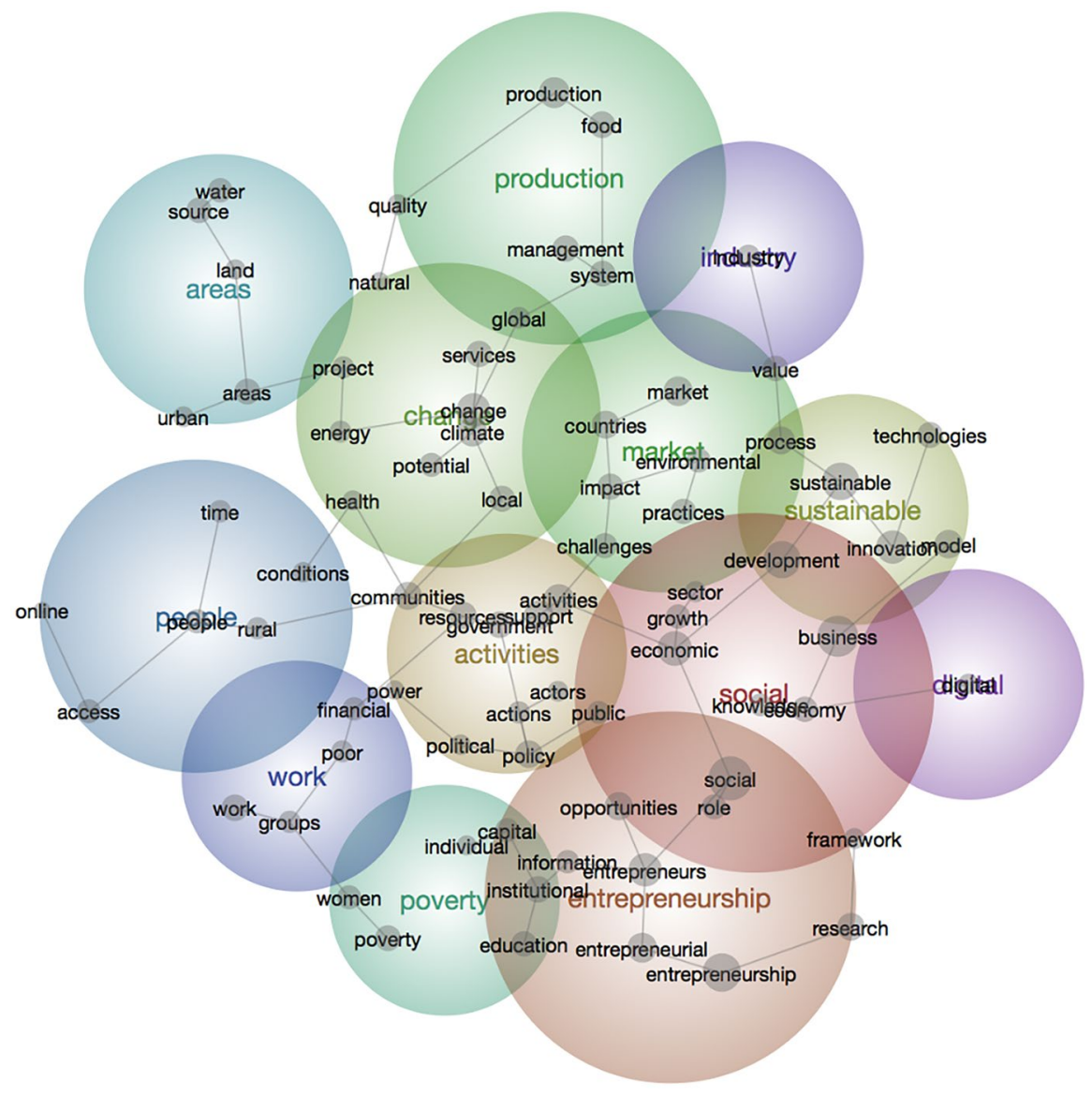

Fig. 2 The semantic map of a selection of scientific literature published from January 2016 to June 2021 on entrepreneurship and grand challenges (elaboration aided by Leximancer)

entrepreneurship: the concepts of work, and even more, that of activities, have become core to the scholarly conversation, with the activities concept strictly linked to relevant political concepts, that is, communities, resources, actors, power, policy, public.

The theme digital, which was completely absent in the pre-2016 semantic map (i.e., did not show up at all, even as a second-order keyword) is present as a first-order concept in the post-2015 semantic map. Perhaps even more interestingly, the digital theme strongly overlaps with the sustainable and social themes, thus confirming that the digital transition is increasingly perceived as converging with the sustainability transition (George et al., 2020): two challenges that must be addressed in an integrated fashion, and cannot be addressed without a quantum leap in entrepreneurial attitudes and capacities. 


\section{Entrepreneurship and grand challenges: The evolution of research streams}

The semantic analysis described above suggests that the very scope of entrepreneurship research is shifting, along with the mindset and preoccupations of most researchers. Unsurprisingly, the research streams in the entrepreneurship field have multiplied and are challenging the very foundations of traditional entrepreneurship research, such as its rooting in classical economics, its view of the entrepreneur as a rent-seeker, and the clear distinction of the roles between market and state actors (Muñoz \& Cohen, 2018).

Thus, to complement the semantic analysis presented, we conducted a manual mapping of the evolution of research streams in the literature to gain an idea of the trends associated with research on the role of entrepreneurship in the face of grand challenges. The idea was to discover how the research community is selforganizing into subcommunities to address the new emerging themes and challenges related to entrepreneurship and grand challenges.

To do so, we leveraged the literature reviews and state-of-the-art papers identified via the Scopus search described (particularly, Anand et al., 2021; Apostolopoulos et al., 2018; Fellnhofer et al., 2014; Kraus et al., 2018; Sarango-Lalangui et al., 2018; Sutter et al., 2019), along with five recent and relevant special issues published in the Journal of Management Studies (Markman et al., 2016); the International Journal of Entrepreneurial Behavior and Research (Muñoz et al., 2018); Academy of Management Perspectives (Markman et al., 2019); Small Business Economics (Volkmann et al., 2021); and Business Strategy and the Environment (Genus, 2021).

These sources suggest that there has been a huge flourishing of research streams dedicated to what is often labelled as "nonconventional entrepreneurship". These streams investigate how entrepreneurs, as uncertainty-handlers and opportunity-seizers, leverage their abilities and energies to pursue goals that can also differ from rent-seeking and individual interest. This explosion of diverse streams can be viewed as a divergent phase in entrepreneurship research, with a polarization emerging between conventional and nonconventional entrepreneurship research and practice.

The numerous streams (Apostolopoulos et al., 2018; Crecente et al., 2021) that characterize this divergent phase can be clustered into three main groups of "nonconventional" research areas (Fig. 3, left), each with a specific disciplinary and theoretical background.

The first group is "green entrepreneurship", also called "environmental entrepreneurship" or "ecopreneurship", which deals with the possible contributions of entrepreneurial action to improved environmental impact (Doh et al., 2019). Scholars engaged in this research area may have an interdisciplinary background including competences in engineering or life sciences, sometimes with a scientific mindset based on systems thinking.

The second group is social entrepreneurship, which deals with the possible contributions of entrepreneurial action to social inclusion and justice (Gupta et al., 2020). Scholars engaged in this research area may have an interdisciplinary 


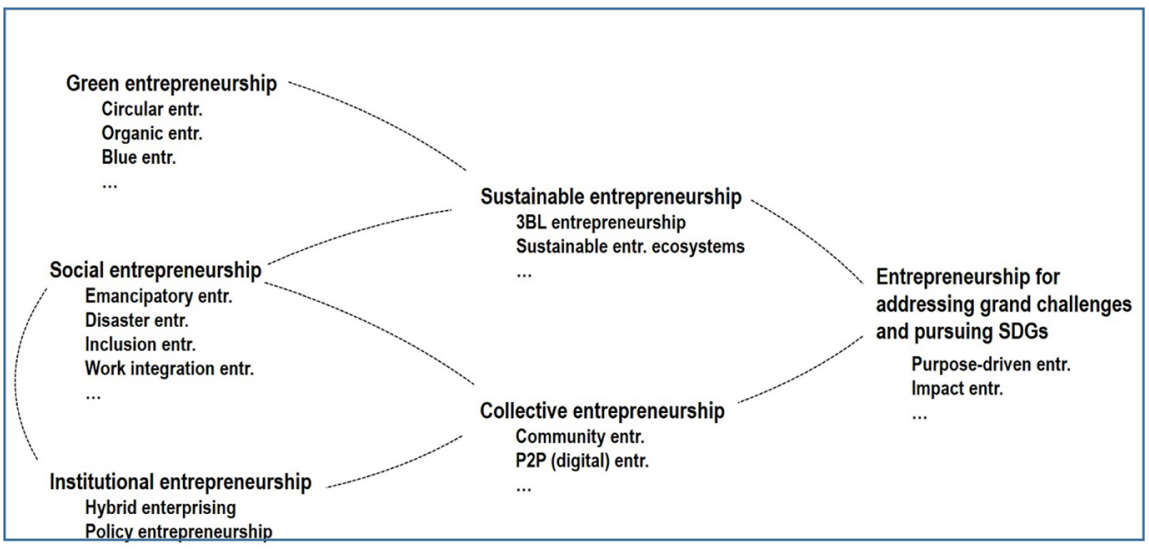

Fig. 3 The evolution of research streams from nonconventional entrepreneurship toward grand challenges entrepreneurship (source: Authors' elaboration)

background including competences in social sciences, sometimes with a scientific mindset based on community and regional development studies.

The third group is institutional entrepreneurship, which deals with the possible contributions of entrepreneurial action to the co-creation of an institutional environment (e.g., laws, norms, technological standards, social expectations) that is favorable to sustainable development (Pacheco et al., 2010). Scholars engaged in this research area may have an interdisciplinary background including competences in governance and organizational sciences, sometimes with a scientific mindset based on social embeddedness studies.

The three aforementioned research streams have developed independently, in parallel lanes, for some years. However, after this divergent phase, marked by flourishing idea multiplication, a convergent phase of this research area has begun. As depicted in the central part of Fig. 3, a first, key convergence movement has occurred in the literature between green and social entrepreneurship, with "sustainable entrepreneurship" as a label that usually identifies entrepreneurship that pursues both social and environmental sustainability (Markman et al., 2019; Muñoz \& Cohen, 2018; Pacheco et al., 2010; Schaltegger \& Wagner, 2011). However, both social and institutional entrepreneurship are rooted in the literature dealing with institutional logics and hybrid organizing (Anand et al., 2021). Therefore, while some scholars understand sustainable entrepreneurship to refer to a merge between green and social entrepreneurship, others also include institutional entrepreneurship in the concept of sustainable entrepreneurship (Schaltegger \& Wagner, 2011).

Sustainable entrepreneurship scholars often adopt the 3BL approach to investigate entrepreneurial action and performance (Belz \& Binder, 2017). 3BL is an approach to sustainability based on recent developments in accounting studies, focusing on the firm as the level of analysis. This approach is based on the idea that organizations should balance their actions to pursue not only financial performance, but also (measurable) social and environmental impact. However, an increasing number of 
scholars is focusing on a wider level of analysis, including the contextual factors of sustainable entrepreneurship, and leverages the literature on entrepreneurial ecosystems (Cavallo et al., 2018) to further develop the idea into the concept of sustainable entrepreneurial ecosystems (Volkmann et al., 2021).

Besides the convergence of social and green entrepreneurship into sustainable entrepreneurship, the strongly overlapping background and scope of social and institutional entrepreneurship has resulted in a second, specific convergent movement. Scholars from both subcommunities have developed a growing interest in collectives supporting entrepreneurs (Markman et al., 2019; Soderstrom \& Heinze, 2021) and collective entrepreneurship (Wijen \& Ansari, 2007a, b), as opposed to the traditional, individualistic and "hero" view of the entrepreneur. This new area includes streams such as community entrepreneurship, and focuses on the relationship between entrepreneurship and the development and protection of the common good (Peredo \& Chrisman, 2006) and peer-to-peer entrepreneurship, and includes a growing stream on the role of digitization and the digital commons (Kostakis et al., 2018) in the just transition toward a sustainable future.

However, despite the literature on sustainable entrepreneurship being quite young, dissatisfaction around the concept of sustainable entrepreneurship is already growing because this very concept conveys the idea that entrepreneurship, per se, is a burden for the planet and society that can be reduced only to the point of becoming, to some extent, more bearable (Markman et al., 2016). This idea is implicitly but powerfully implied by the 3BL approach (Muñoz \& Cohen, 2018), which instills a firm-centric view based on rent-seeking and/or legitimacy-seeking as key driving forces (de Clercq \& Voronov, 2011). Conversely, according to the critics, a sort of Copernican revolution is needed to understand the role of entrepreneurship (Klapper et al., 2021; Markman et al., 2016). In Copernicus's scientific revolution, the Sun replaces the Earth as the celestial body around which the other celestial bodies revolve; similarly, entrepreneurship should become a central regenerative force that does not limit itself to becoming less unsustainable, but strives to develop new opportunities to make the social-ecological system resilient and thriving (Schaefer et al., 2015).

However, criticism is also emerging against the rhetoric of collective entrepreneurship. Such criticism argues that entrepreneurial decisions and actions being collective or community based does not necessarily mean that these decisions and actions will not have negative consequences at the system level (Jones et al., 2019).

For all these reasons, a further wave of research streams is emerging that seeks to integrate the most interesting and innovative ideas emerging from the nonconventional entrepreneurship debate and to take the role of entrepreneurship to another level (Fig. 3, right). Some labels have been proposed to indicate this innovative view of entrepreneurship as a proactive, systemic force designed to address grand challenges. Labels such as "impact entrepreneurship" (Markman et al., 2019) and "purpose-driven entrepreneurship" (Muñoz \& Cohen, 2018) have gained traction, but other labels have also been proposed, such as "sustainability-as-flourishing entrepreneurship" (Schaefer et al., 2015).

This evolution suggests that nonconventional entrepreneurship as a field of studies is evolving from a peripheral to a transformative research area, with the ambition 
of overcoming the divide between conventional and nonconventional entrepreneurship and of rethinking the very assumptions and normative frameworks (Grimes \& Vogus, 2021) that have guided entrepreneurship research thus far (Muñoz \& Cohen, 2018).

\section{Entrepreneurship and grand challenges: New emerging theories and approaches}

As the two previous sections have demonstrated, a huge shift is occurring in the core themes, values, and research streams of entrepreneurship studies. This shift is so dramatic that the traditional theories, rooted in classical economics, that were commonly used to explain entrepreneurship before the nonconventional entrepreneurship revolution are no longer sufficient (Muñoz \& Cohen, 2018). New views and approaches are needed to effectively explain how and why entrepreneurship can contribute to grand challenges. This section describes the ongoing efforts to identify, integrate, and consolidate these new views.

The vivacity of the ongoing theoretical debate is mirrored by the high-quality special issues that have been recently published (Anand et al., 2021). Therefore, we leveraged the following five special issues, published in the Journal of Management Studies (Markman et al., 2016); International Journal of Entrepreneurial Behavior and Research (Muñoz et al., 2018); Academy of Management Perspectives (Markman et al., 2019); Small Business Economics (Volkmann et al., 2021); and Business Strategy and the Environment (Genus, 2021).

The articles published in these special issues are a rich and up-to-date source for a backward literature search, thus allowing us to identify several further interesting publications, including agenda-setting articles. In addition, some articles in these special issues are important agenda-setting publications in their own right.

This literature analysis led us to identify several publications that provide very interesting overviews of real-world cases in which entrepreneurship contributes to addressing grand challenges and pursuing the SDGs (Günzel-Jensen et al., 2020; Horne et al., 2020; Littlewood \& Holt, 2018; Moon, 2018). Other recent publications provide accurate overviews of the literature focusing on the entrepreneurship - grand challenges nexus (Kraus et al., 2018; Sarango-Lalangui et al., 2018). While acknowledging the relevance of these review studies, we concentrated on publications that explicitly propose an agenda for future research. These publications provide a map of key research streams and/or discuss which theoretical lens(es) could best contribute to improved understanding of the role of entrepreneurship in addressing grand challenges. We focused on agenda-setting studies published since 2015, the year in which the SDGs were approved by the United Nations.

Our goal was to identify a highly focused selection of recent and authoritative articles with a strong agenda-setting purpose, explicitly advocating at least one theory or approach, with the authors justifying their choice of specific theories or approaches in light of the evolution of the entrepreneurship research field toward a new role of entrepreneurship in addressing grand challenges and/or the SDGs. 
After in-depth discussion, we selected 19 articles. We analyzed these articles carefully to understand the theoretical views or approaches advocated in the studies, and the reasons why the authors of each article deem that a certain theory or approach is best suited to shape a new generation of studies on entrepreneurship as key to addressing grand challenges. In some cases, we found that the article under analysis advocated a single theory or approach (e.g., stakeholder theory). In other cases, we found that the article under analysis advocated the joint use of two, or even more, complementary theories or approaches (e.g., stakeholder theory and Ostrom's theory of the governance and management of the commons). This allowed us to conduct a network analysis (Fig. 4) to gain a synthetic overview of which theories and approaches are advocated by the literature under analysis, and how these theories and approaches are viewed as (at least potentially) usefully collaborating with each other for building a meta-theory of entrepreneurship with stronger explanatory and normative power in the face of grand challenges.

As synthesized in Fig. 4, we found that a very interesting new theoretical landscape is emerging. In this landscape, rather than a proliferation of rival theories, a meta-theory or grand theory of entrepreneurship is emerging, that consists of a network of strongly complementary theories from both within and without the boundaries of traditional business research. This emerging integration across

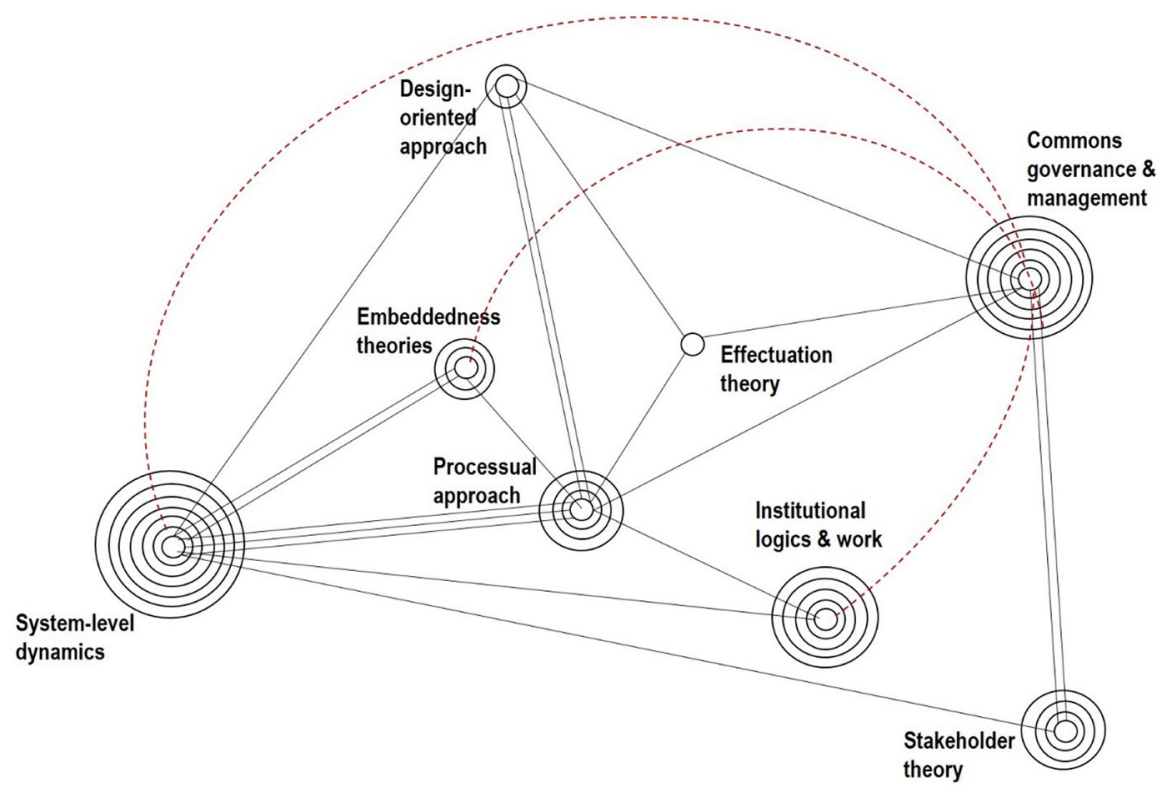

Fig. 4 Network analysis of the theories and approaches advocated in the 19 recent agenda-setting articles listed in Tables 1,2 and 3. The number of circles corresponds to the number of articles in which a theory or approach is explicitly advocated. The number of lines corresponds to the number of articles in which the two linked theories or approaches are explicitly co-advocated. Red dotted lines represent crossfertilizations that are already strongly present in the literature (even if not explicitly advocated by the articles under analysis) 
complementary theories is consistent with the convergent phase observed in the previous section and depicted in Fig. 3.

The new emerging theoretical landscape revolves around two poles: systems thinking (and specifically a call to prioritizing the analysis of system-level dynamics) (Meadows, 2009) and Ostrom's work on the governance and management of the commons (Ostrom, 1990). Both approaches are not native to business studies, but as Fig. 4 demonstrates (see the number of circles representing the number of articles in which a theory is advocated), they may have strong potential in the eyes of the scholarly community to reshape entrepreneurship in the face of grand challenges. Other theories and approaches from the business and management literature emerge as a connecting tissue between these two major poles in the network analysis depicted in Fig. 4. These are embeddedness theories; stakeholder theory (especially in its newest, less firm-centric forms); the theories on institutional logics and institutional work; the processual approach; effectuation theory; and the design-oriented approaches.

In the following subsection, we synthesize the role played in the emerging theoretical landscape by the two major poles (system-level dynamics and commons governance and management) and the other theories and approaches bridging these two major poles.

\section{System-level dynamics}

The basic idea of systems thinking is that human action cannot be effective (especially in the middle and long term) unless it is based on a good understanding of systems (Isaksson, 2019; Meadows, 2009). A system can be conceptualized as a loop (or set of interconnected loops) of cause-effect dynamics between factors and/or events that, by recurring over and over in cycles, structurally influence a certain configuration and/or resource level (e.g., see Abdelkafi \& Täuscher, 2016). Systems are particularly valuable if their functioning stabilizes a desirable configuration and/or optimizes the level of a certain resource for collective benefit (Fanning et al., 2020). For example, a healthy natural ecosystem regenerates a configuration in which biodiversity is maximized; similarly, a successful value chain is composed of dynamic loops that keep employment and profits at high levels. However, systems may also destroy resources or lose their capacity to keep a configuration stable for the collective benefit. For example, this is what is happening to our food system, which contributes to jeopardizing the global climate due to the methane emissions of breeding farms. In contrast, the mafia is an example of a system that stabilizes an extractive configuration of the society in which it operates and generates resources for the few by destroying resources for the many.

Systems have a circular nature, that is, they are composed of sequences of processes that, through feedback loops, reinforce or weaken the repetition of those very same processes and/or their consequences in ways that may be very complex and highly counterintuitive. Further, many relevant systems are nonlinear: changes in outputs may be (even dramatically) not proportional to changes in inputs (Meadows, 2009). 
In this light, entrepreneurship should contribute to developing and/or protecting "good" systems that stabilize flourishing configurations and regenerate resources for the collective benefit (Lüdeke-Freund, 2020; Schaefer et al., 2015). This idea is not alien to the mainstream entrepreneurship literature. For example, the Schumpeterian entrepreneur is called to contribute to the loop that generates economic growth by continuously triggering the creative destruction of old business models (Schumpeter, 1934). However, the Schumpeterian view is considered insufficient in the face of grand challenges for at least two reasons. First, entrepreneurs should contribute to the system that generates sustainable development, and not merely economic growth. That is, the system for which entrepreneurs should consider themselves co-responsible is the entire social-ecological system, rather than the mere economic system, which should not be artificially separated from the social-ecological system in which it is embedded (Muñoz \& Cohen, 2018). Second, as opposed to Schumpeter's optimistic view that the entrepreneurs' fervid distributed experimentation has, per se, positive consequences for the system's performance, we should acknowledge that social-ecological systems have many possibly hidden and nonlinear fragilities and therefore that any "creatively destructive" entrepreneurial action may have disruptive system-level consequences, particularly in the middle and long term (Nyström et al., 2019).

Besides being expected to contribute to (good) systems, entrepreneurs also depend on systems. For example, tourism entrepreneurship may depend on a certain place's clean seaside and welcoming atmosphere. Digital entrepreneurship may depend on the support of incubators and venture capitalists. Again, the mainstream entrepreneurship literature has already begun to explore these interdependencies, and has developed the concept of a (sustainable) entrepreneurial ecosystem as the system that makes entrepreneurial action possible and maximizes its potential (O'Shea et al., 2021). However, scholars who are attentive to complain that studies on entrepreneurial ecosystems have so far often limited themselves to identifying "laundry lists" of the entrepreneurial ecosystem's key actors and with what these actors are expected to provide entrepreneurs, thus paradoxically failing to understand the systemic nature of entrepreneurial ecosystems (Cavallo et al., 2018). Such scholars urge the research community to investigate the key dynamics (Anand et al., 2021), that is, the possible expected and unexpected cause-effect loops, of entrepreneurial ecosystems, and the long-term effects of these dynamics on entrepreneurial action and the larger social-ecological system.

In the basket of 19 recent and representative agenda-setting articles that we selected for analysis of the emerging theoretical landscape around the entrepreneurship - grand challenges nexus, seven advocate the analysis of system-level dynamics as a key approach. These seven articles are listed and synthesized in Table 1.

\section{Commons governance and management}

The basic idea of the theory of the commons, as it has evolved after Ostrom's Nobel Prize winning research (Dietz et al., 2003; Ostrom, 1990, 2010; Ostrom et al., 1999), is that human fate strongly depends on resources that are (or could be) available for a certain community's collective benefit, but whose availability is vulnerable to the behaviors of that very community's members (Hardin, 1968; Hess, 2008). Examples 


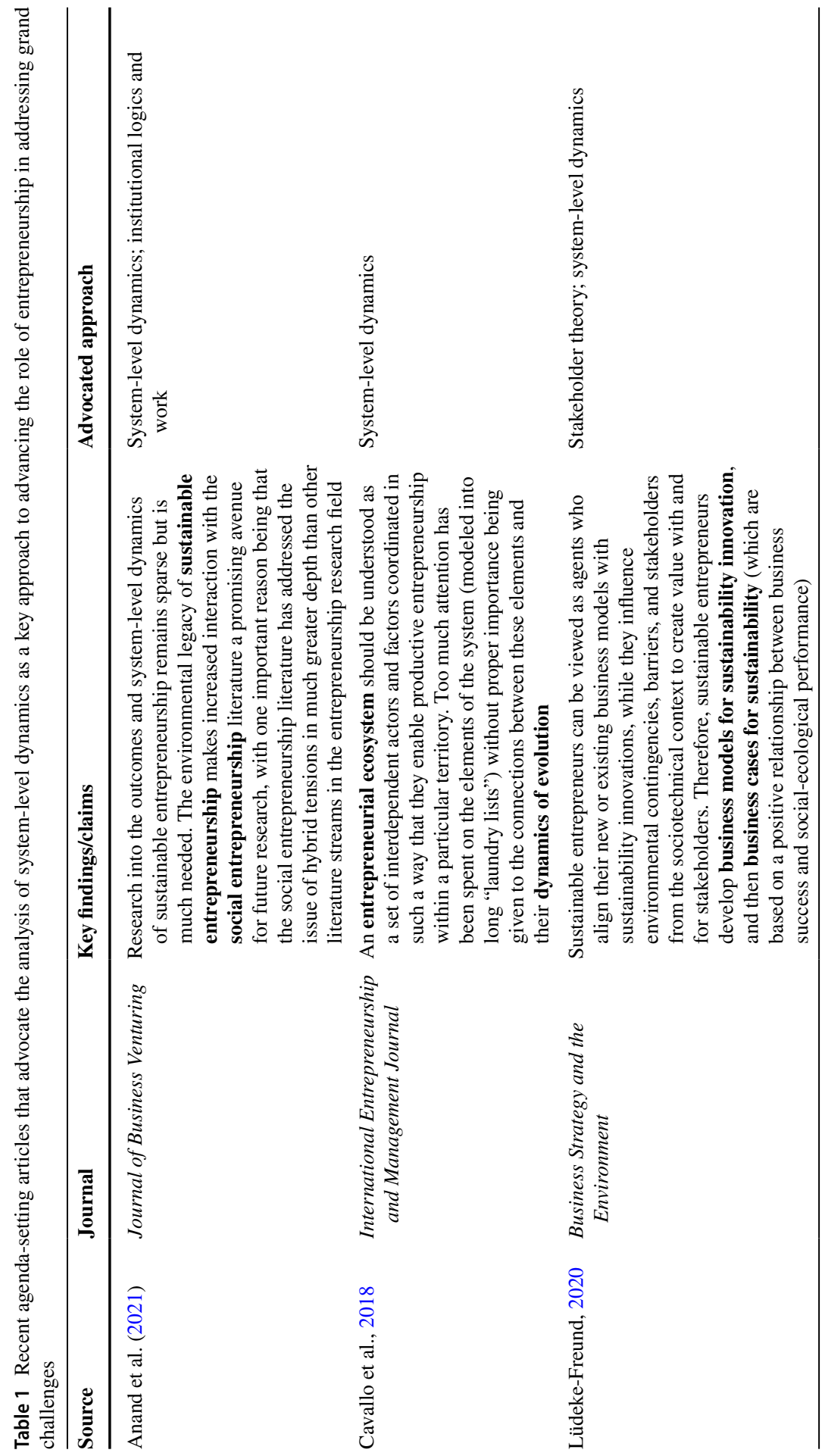




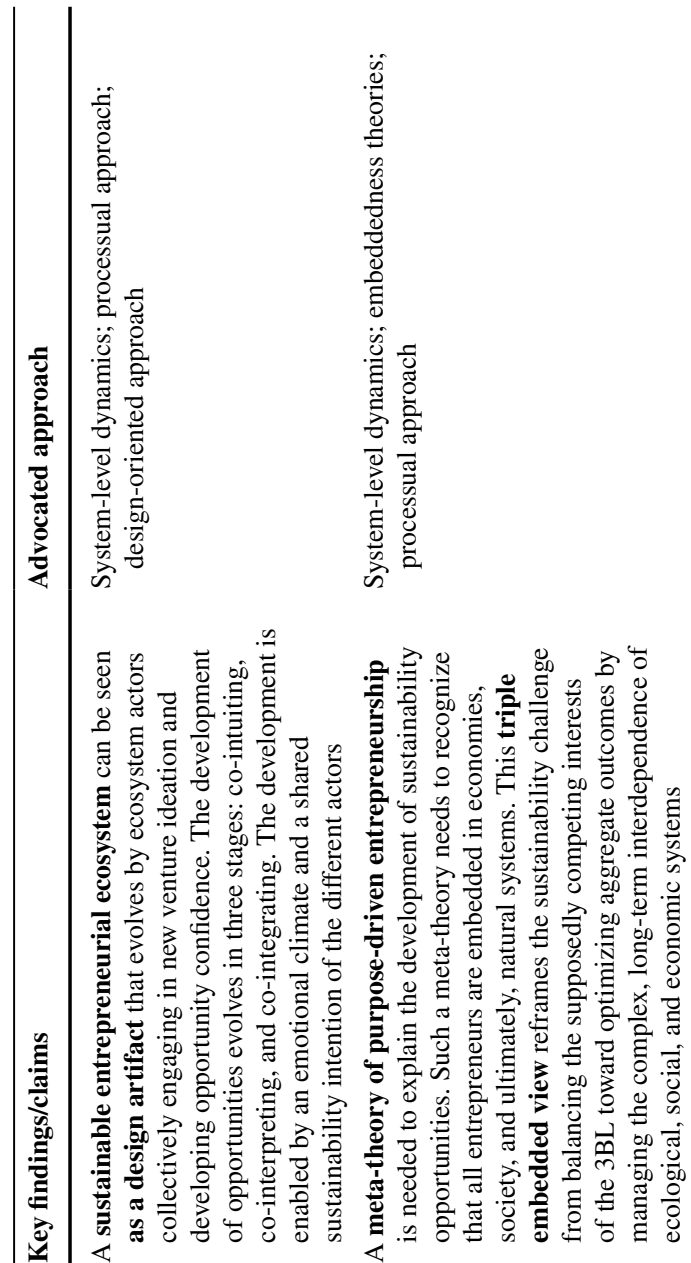

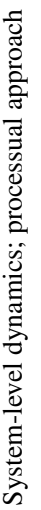

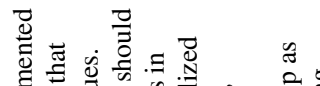

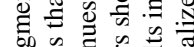

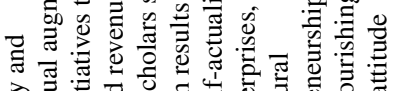

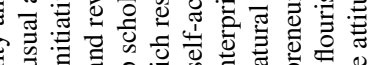

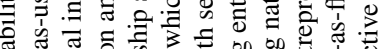

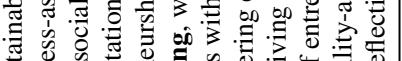

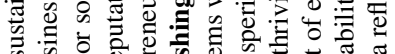
की

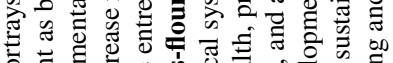
के

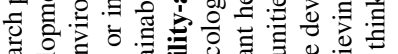

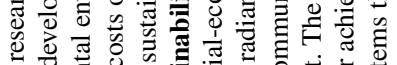

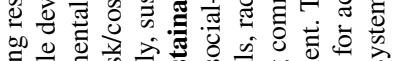

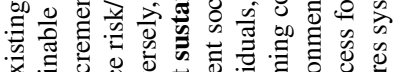

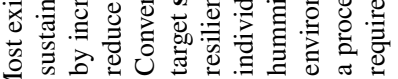

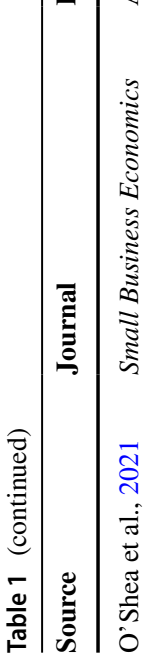
בี

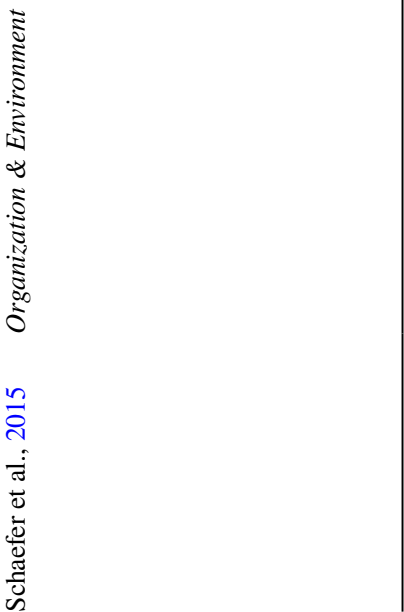




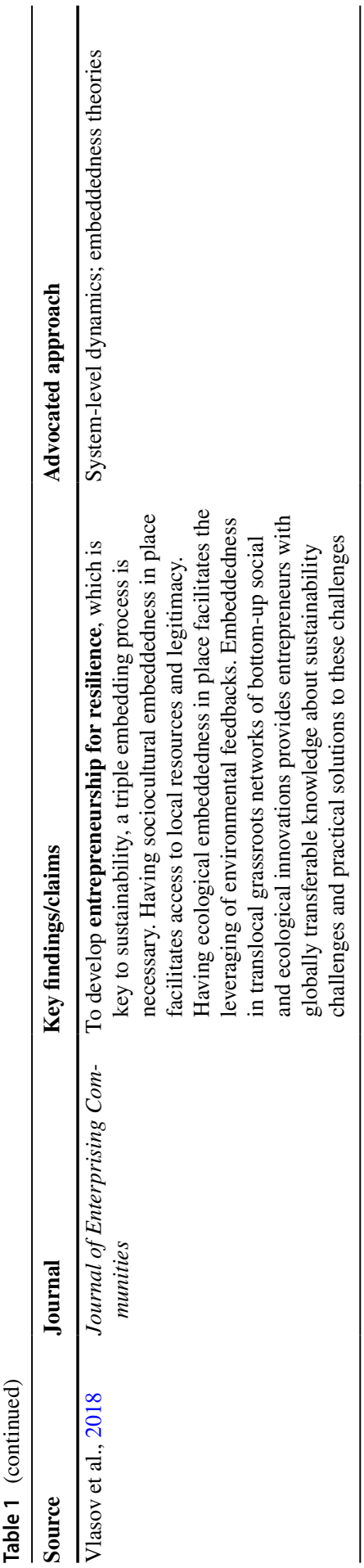


include the attractiveness of a tourist destination, the reputation of an industrial district, the fish in a marine area, the quality of the contents in a wiki, a health care system's capacity during a pandemic, and the stability of the global climate.

In each of the examples listed above, there is a community (ranging from small to global) that directly benefits form a resource, but whose misbehaviors may result in that resource becoming unavailable. For the resource to remain available for the collective benefit, a sufficient rate of beneficiaries must voluntarily refrain from overexploitation and/or carelessness, and take responsibility for the commons at stake. The debate on the commons began in economics and political sciences (Standing, 2019), but has recently gained significant traction in business and management studies (Ansari et al., 2013; Fjeldstad et al., 2012; Peredo et al., 2020), and particularly in organization studies (Ricciardi et al., 2020a, b; Rossignoli et al., 2018), sometimes by cross-fertilizing the theory of the commons (Albareda \& Jose, 2020) with the theory of the common good of the firm (Higgins et al., 2014).

When a commons is at stake, then, a social dilemma is presented to beneficiaries: they might choose short-term, individual benefit (e.g., by saving the time and money that best-practice waste management would require), thus increasing the risk that the long-term, collective benefit will be lost (e.g., because of urban decay, or waste taxes increase), or they might choose to contribute to the long-term, collective benefit at the price of short-term individual benefit. As game theory experiments reveal, people hate the idea of engaging in pointless sacrifices, and may hate even more the idea that others, particularly the cheaters, might unfairly benefit from the sacrifices of others (Abele et al., 2010; Frischmann et al., 2019). Therefore, commons beneficiaries will likely contribute to the commons only if they have reason to believe that a high number of other beneficiaries will do the same, thus making the sacrifice useful and the reward (sufficiently) fair. For example, even when tourists begin abandoning a destination because it is dirty, the individual hotel owner is not likely to adopt best-practice waste management behaviors if most businesses in that tourist destination have so far cheated waste management regulations to save money. Thus, unfortunately, each individual misbehavior reinforces misbehaviors on the part of the others. In such scenarios, the role of organization and management sciences is likely to become increasingly relevant given that there is growing awareness that real-world commons do not merely raise social dilemmas, but pose sense-making, business and coordination challenges nested in social dilemmas (Abele et al., 2010; Adams et al., 2003).

That is, when a commons is at stake, beneficiaries' behaviors influence each other in vicious or virtuous cycles, depending on a set of boundary conditions that Ostrom (Ostrom, 2009, 2010), and other scholars after her, have begun to identify. The presence of these loops highlights the systemic nature of the commons. Indeed, the socalled "tragedy of the commons" (Hardin, 1968) is a self-perpetuating vicious cycle that results in the destruction of the common resource. The tragedy of the commons is based on loops of "get it while you can" or "I won't be the only fool who contributes" individual choices, and has been clearly identified as a systemic archetype by the seminal work of Meadows (2009)_Thinking in Systems.

In addition, one of the most viable research streams stemming from Ostrom's work, that is, the stream on social-ecological system resilience and adaptive co-management 
(Berkes, 2009; Bodin, 2017) explicitly conceptualizes environmental commons (e.g., marine areas) as complex social-ecological systems that need to be collaboratively understood, modeled, governed, and managed as such (Ricciardi, De Bernardi, et al., 2020). Therefore, even if systems thinking and the theory of the commons are not explicitly co-advocated for their joint explanatory power by the 19 articles selected for this analysis, the existing theoretical link between these two approaches is strong and loud, as is represented by one of the red dotted lines in Fig. 4.

Based on the synergies and complementarities of the systemic and commons approaches, we conceptualize their joint explanatory and normative power as follows. The development and protection of systems that are able to regenerate collective benefit are core to addressing grand challenges, as argued in the previous section, but almost all these collective benefit systems embed commons-related dynamics (Ansari et al., 2013; Hess, 2008). That is, the systems that are relevant to grand challenges are typically threatened by the tragedy of the commons (triggered by beneficiaries' loafing and/or overexploitation behaviors). In this light, we suggest that the role of entrepreneurship in the face of grand challenges is twofold.

First, entrepreneurs should not be among those who contribute to reinforcing a commons-related vicious cycle. This concretely translates into not only sustained compliance to state-of-the-art behaviors, but also into assurance of transparency, because when a commons is at stake even the suspicion that others are misbehaving reinforces the vicious cycle.

Second, and much more ambitiously, entrepreneurs should be among those who contribute to reinforcing a commons-related virtuous cycle. This implies viewing entrepreneurial action, and its continuous experimentation processes, as a means of participating in the never-ending effort to learn about the system's dynamics and adaptively develop ever-improving solutions that serve the system's health and resilience and that are economically sustainable (Sigmund et al., 2010). This "commonsactivist entrepreneur" may play a way out of the so-called prison of social dilemmas (Pacheco et al., 2010) and shape the system for collective benefit.

In the basket of 19 recent and representative agenda-setting articles that we selected for the analysis of the emerging theoretical landscape around the entrepreneurship - grand challenges nexus, six advocate the analysis of system-level dynamics as a key approach. These six articles are listed and synthesized in Table 2.

\section{Bridging approaches: Embeddedness, stakeholders, institutions, design, processes, and effectuation}

As illustrated in the two previous sections, the two key theoretical poles identified in Fig. 4 jointly draw a high-level view of what the role of entrepreneurship in the face of grand challenges should be. That is, it should contribute to developing and/or protecting relevant systems for the collective benefit, and particularly to codeveloping commons-related virtuous cycles (feedback loops) in these systems, or at least refraining from actions that are acknowledged as strengthening commonsrelated vicious cycles. In other words, entrepreneurship should actively contribute to benefit rather than simply passively not contribute to damage. 


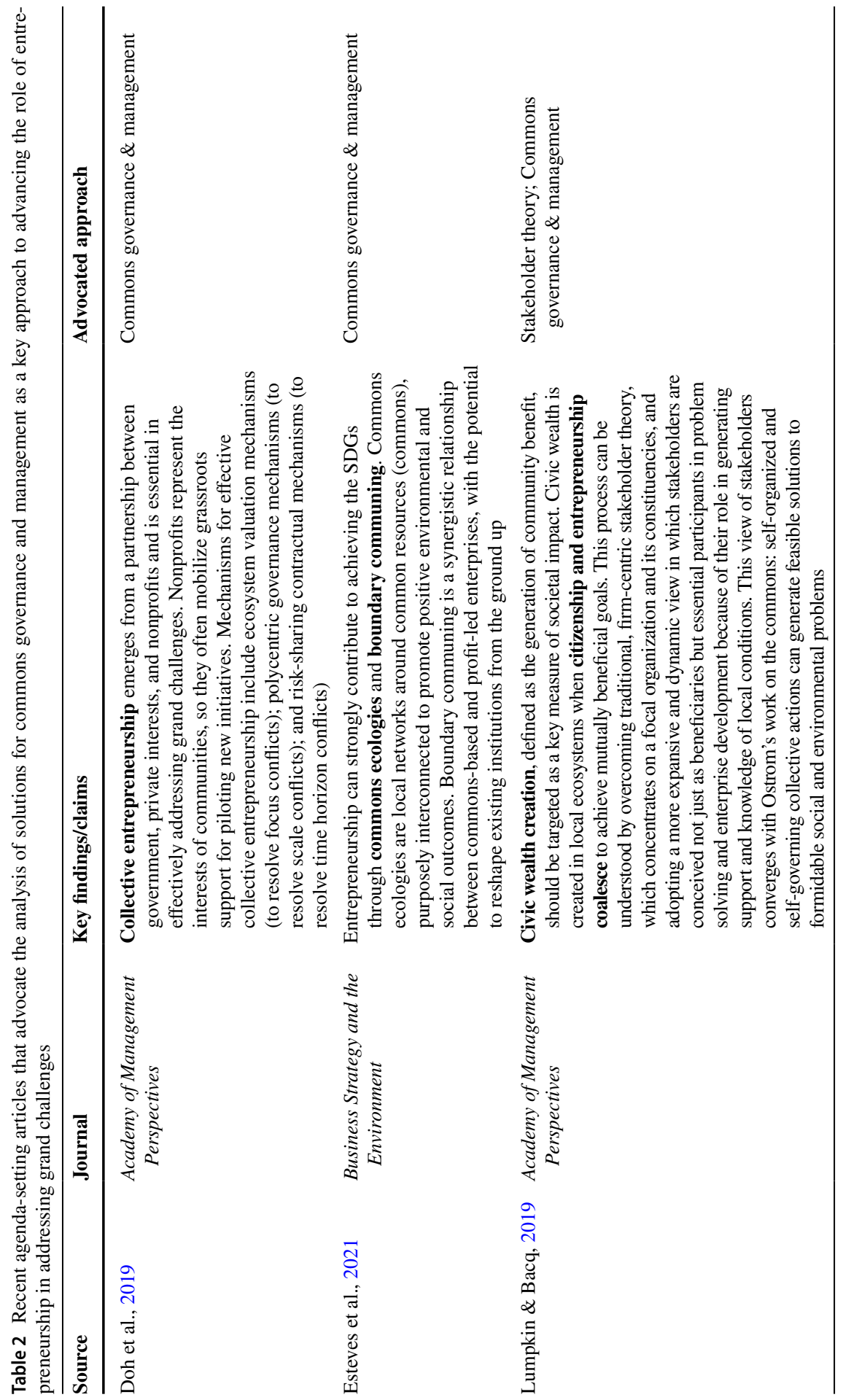




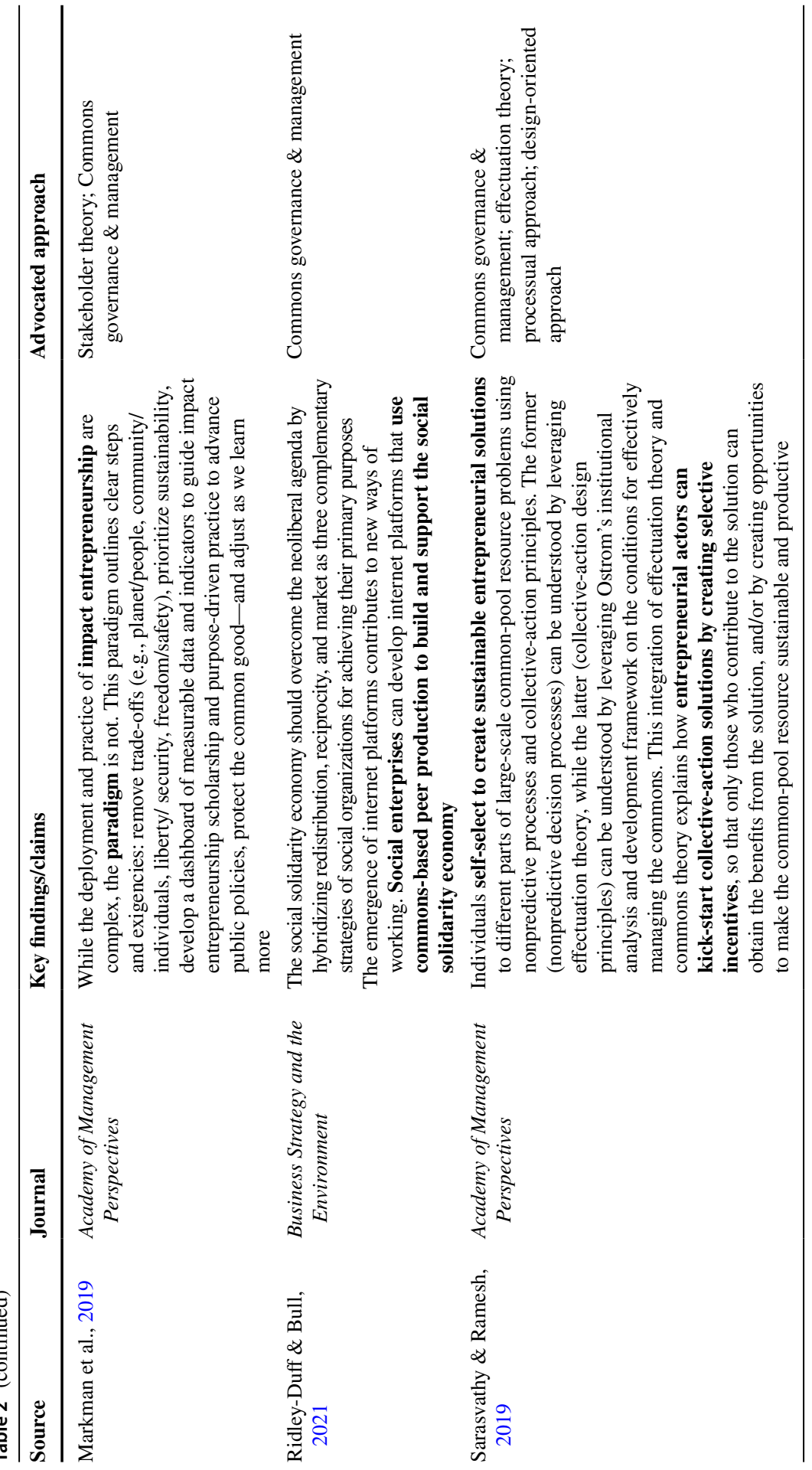


However, how can entrepreneurs concretely play this role in an effective way? Systems and commons thinking provide us with a new generation of clear and measurable general objectives, but they provide little, if any, concrete detail on how to achieve these objectives, and particularly on which entrepreneurial actions on the ground might really contribute to shifting from vicious to virtuous cycles at the system level.

The literature, and particularly the 19 recent agenda-setting articles that we review in this section, has already provided an interesting set of possible answers by identifying theories and approaches whose explanatory and normative power has been widely tested in the business and management literature, and that have proved sound and effective in translating goals into concrete working organizations and/or solutions that are also economically self-sustaining. As Fig. 4 demonstrates, these approaches overall draw a theoretical network linking the systemic and the commons approaches with a connective tissue that is hard-wired in today's ongoing debate in the business and management disciplines.

The first group of approaches that play this bridging role in Fig. 4 is related to the social behaviors of the entrepreneur and includes the embeddedness, stakeholder, and institutional approaches. Social embeddedness theories have a long tradition in entrepreneurship research, dating back to the Austrian school and particularly Lachmann's (1976) research. The entrepreneur is viewed as strongly embedded in its context, acting as a catalyst of social learning (Cantino et al., 2017). Embeddedness occurs at several levels. For example, sociocultural local embeddedness enables attaining help to develop the initiative; ecological embeddedness enables the granular collection and understanding of environmental feedback; community of practice embeddedness enables knowledge exchange and open innovation (Vlasov et al., 2018). As in the case of the link between systemlevel analyses and the governance and management of the commons, the link between social embeddedness and the commons approach is soundly present in the literature, although not explicitly advocated in the 19 articles under analysis. Self-organizing and participatory architectures for commons-related learning have been acknowledged as key to the governance and management of the commons (Ricciardi et al., 2020a, b). Again, this meta-theoretic link is represented by one of the red dotted lines in Fig. 4.

Further, entrepreneurs play a specific role in embedding their initiatives in a dynamic network of stakeholders. The stakeholder theory has significantly contributed to translating the embeddedness idea into concrete practices and performance measurement criteria. However, the time is ripe to develop a sounder theory of stakeholder governance and management (Amis et al., 2020). Scholars increasingly suggest overcoming the traditional, firm-centric versions of the stakeholder theory, and adopting a more systemic, commons-like view where stakeholders are not just beneficiaries but essential participants in problem solving and enterprise development because of their knowledge of local conditions and the role they can play in generating support (Lumpkin \& Bacq, 2019). Unsurprisingly, the stakeholder approach is strongly linked with both the commons and the systems approaches, as presented in Fig. 4. 

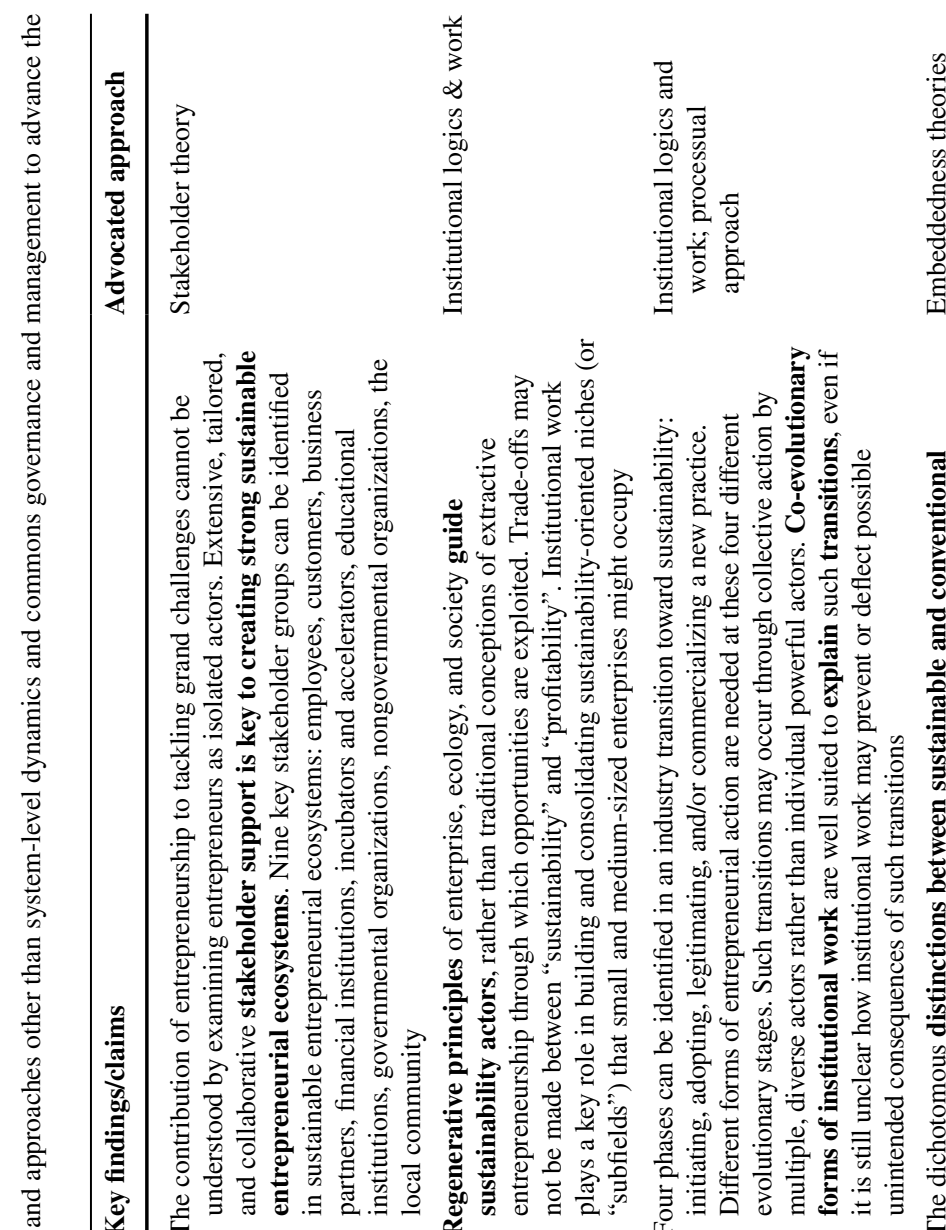

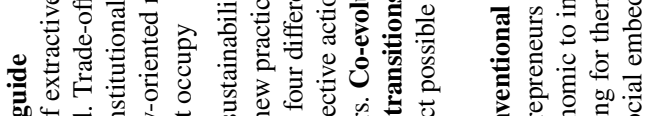
क人

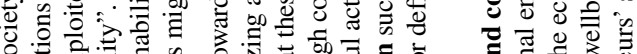

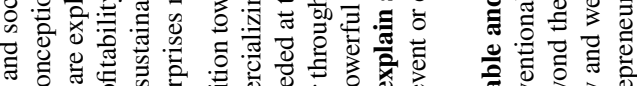
ठ ठ च

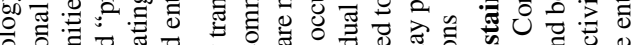

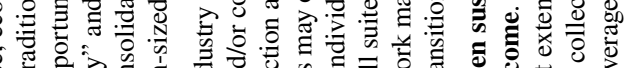

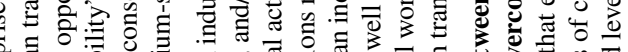

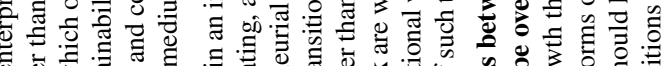

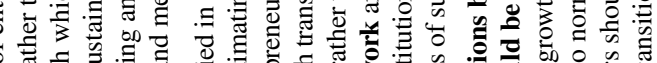

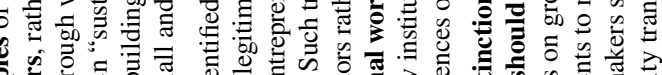

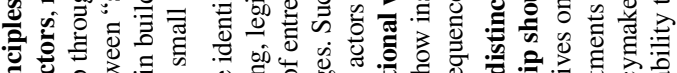

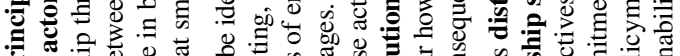
น

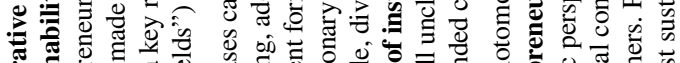

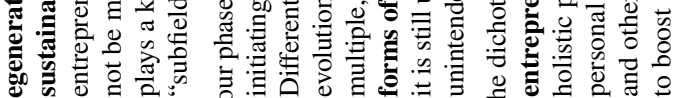

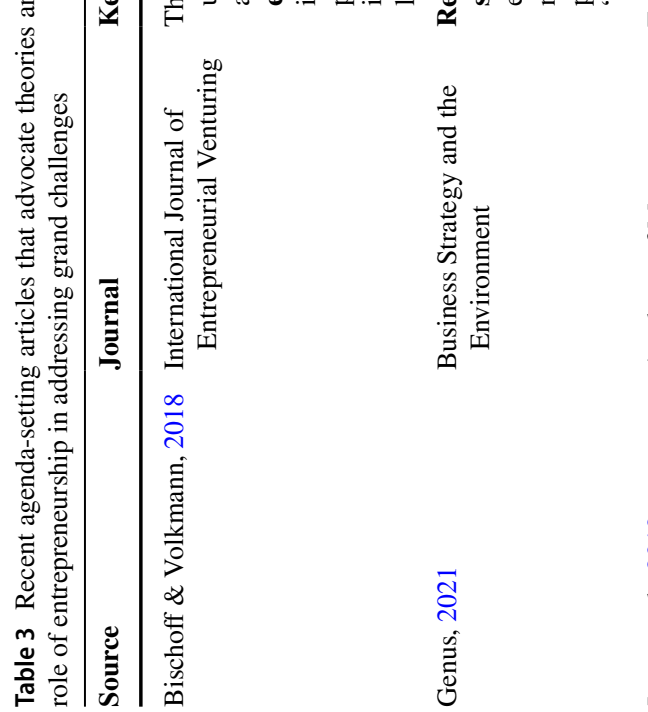

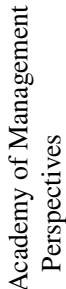

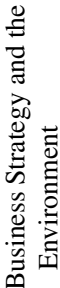
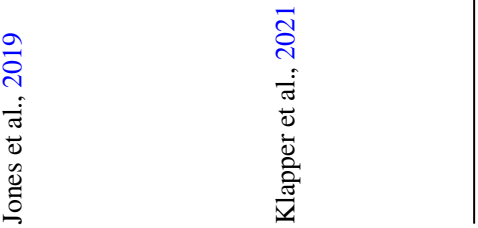


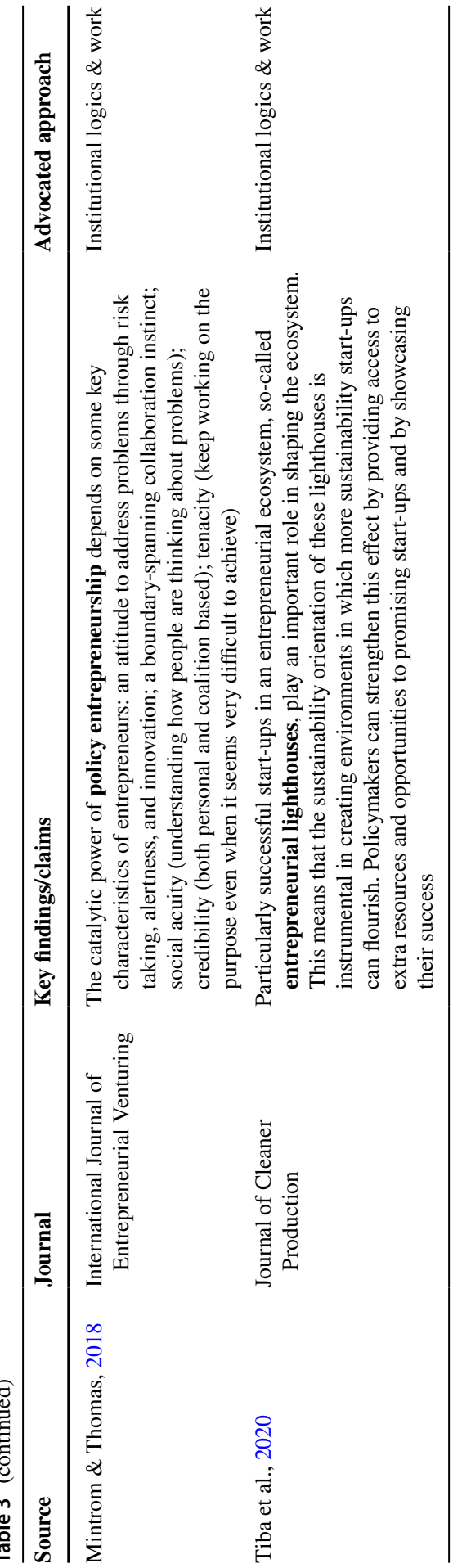


While stakeholder views focus on actor-to-actor embeddedness, the approaches based on institutional entrepreneurship and institutional work focus on actors' embeddedness in social rules and values. Institutional theories view the context in which ventures are embedded as organizational fields (de Clercq \& Voronov, 2011) in which different institutional logics (e.g., market logic or environment protection logic) are created, interact, clash, and evolve (Ansari et al., 2013). Continuous institutional work is needed to create and recreate the conditions for sustainability transitions, which is why the idea of institutional entrepreneurship has gained great traction in SDG-related studies (Wijen \& Ansari, 2007a, b). Institutional work and entrepreneurship are explicitly co-advocated with systemic approaches and commons approaches by the literature (see Fig. 4), starting from Ostrom (1990) herself.

The second group of approaches that play a bridging role in Fig. 4 is related to the concrete cognitive, creative, and decision-making tools that entrepreneurs can adopt to address grand challenges successfully. Design-oriented approaches highlight that systems (including systems shaped by possible social dilemmas) can and should be (re)designed, for example, through sociotechnical approaches (Venkataraman et al., 2012), to make them resilient and capable of regenerating resources for the common good. Entrepreneurs are in a position to play a pivotal role in this never-ending systemic design challenge (O'Shea et al., 2021). Processual approaches (Jones et al., 2019) highlight that business opportunities co-evolve with social-ecological systems and continuous entrepreneurial learning is required to build the contribution of entrepreneurship to the SDGs throughout time. The effectuation approach (Sarasvathy \& Ramesh, 2019) highlights how the specific relationship between the entrepreneur and the world, based on the entrepreneur's capacity to embrace uncertainty and adaptively experiment around ideas and opportunities at hand, is key to the specific contribution of entrepreneurship to addressing grand challenges. The effectuation approach, which is means based (rather than ends based) is considered close to robust action and its dynamics of distributed experimentation (Ferraro et al., 2015). In a very recent article, Grimes and Vogus (2021) argue that the approach resulting from robust action and the effectuation framework may result in entrepreneurial action that, although necessary, is not sufficiently bold and systemic; therefore, entrepreneurs should be reoriented to possibilistic thinking, which prioritizes counterfactual reasoning and a strong focus on long-term and even on unlikely system-level consequences. This recent contribution confirms the emerging need to cross-fertilize the effectuation approach with systems thinking, alongside the theory of the commons.

In the basket of 19 recent agenda-setting articles that we selected for the analysis of the emerging theoretical landscape around the entrepreneurship - grand challenges nexus, six co-advocate at least one of the approaches mentioned in this section and the systemic approach (Table 1); three co-advocate at least one of the approaches mentioned in this section and the commons approach (Table 2); and six advocate at least one of the approaches mentioned in this section without explicitly co-advocating the systemic or commons approaches (Table 3). All of the approaches discussed in this section are co-advocated with the commons or systems approaches by at least one article, as demonstrated in Fig. 4. 
Table 4 Articles in this special issue that contribute to the research streams synthesized revolving around systems thinking

\section{Authors and title}

De Bernardi, Paola; Bertello, Alberto;

Forliano, Canio; Bullini Orlandi, Federico.

Beyond the "ivory tower". Comparing academic and non-academic knowledge on social entrepreneurship

Callegari, Beniamino; Feder, Christophe. Entrepreneurship and systemic consequences of epidemics: A literature review and emerging model

Le Loarne, Séverine; Razgallah, Meriam; Maalaoui, Adnane; Kraus, Sascha. Becoming a green entrepreneur: An advanced entrepreneurial cognition model based on a practiced-based approach

Zucchella, Antonella; Previtali, Pietro; Strange, Roger. Proactive and reactive views in the transition towards circular business models

A grounded study in the plastic packaging industry

\section{Contribution}

This study conducts a comparative network analysis of social entrepreneurship's conceptual structure at both the academic and non-academic levels, considering scientific articles' keywords and Wikipedia webpages' co-occurrences. The results reveal similarities and discrepancies between these two different sources of knowledge, and outline avenues for future studies at the intersection between social entrepreneurship and the research domains of digital transformation, performance measurement, entrepreneurial ecosystems, and ethics

This article shows that in the short term, epidemics trigger a wave of Kirznerian entrepreneurship aimed at reducing the uncertainty generated directly and indirectly by the medical emergency. Conversely, in the long term, as medical uncertainty abates, Schumpeterian entrepreneurship contributes to transforming the post-crisis environment, either supporting or undermining the public reaction to the crisis and determining the path of institutionalization, in the process of defining a new normal. Thus, epidemics could lead to unpredictable socioeconomic and technological improvements, but also to highly undesirable outcomes, depending on the effectiveness of the integration of entrepreneurial capabilities within the public sector

This article examines how entrepreneurs develop the intention to make their venture green, even when "being green" doesn't happen right from the start, or when the company does not operate in a business that is considered green. The study argues that "becoming green" is not a radical process, but is instead strongly influenced by the entrepreneurial praxis the entrepreneur progressively adopts. An illustrative case study reveals how this model works

This study analyzes the transition to circular business models in incumbent entrepreneurial firms in the plastic packaging industry. The results suggest that the circularity challenge raises dilemmas about how to interpret the transition to sustainability. That is, the transition may be interpreted in a reactive way, by prioritizing continuity and compliance with the law. However, the transition may be interpreted in a proactive way based on radical experimentation and openness to change. A multilevel proactive view of the circularity transition is key to transforming the three interconnected levels of analysis (network, entrepreneur, organization) into a proper, sustainability-oriented innovation ecosystem 
Table 5 Articles in this special issue that contribute to the research on the link between entrepreneurial ecosystems and entrepreneurs' contribution to sustainable development

\section{Authors and title}

Audretsch, David B.; Eichler, Georg M.; Schwarza, Erich J. Emerging needs of social innovators and social innovation ecosystems

Dos Santos, Lucas Inacio; Anholon, Rosley; Da Silva, Dirceu; Etulain, Carlos Raul; Sanchez Rodrigues, Vasco; Leal Filho, Walter. Corporate social responsibility projects: Critical success factors for better performance of Brazilian companies and guidelines to qualify professionals and entrepreneurs

Gil-Gomez, Hermenegildo; Oltra-Badenes, Raul; Guerola-Navarro, Vicente; Zegarra Saldaña, Pablo. Crowdfunding: A Bibliometric Analysis

Khatami, Fahimeh; Scuotto, Veronica; Krueger, Norris; Cantino, Valter. The influence of the entrepreneurial ecosystem model on sustainable innovation from a macro-level lens

\section{Contribution}

By conducting an in-depth qualitative analysis of an exemplary territorial context, this exploratory study sheds light on the emerging needs of social innovators. Further, through an analysis of the identified needs of the entrepreneurs, the study explores similarities and differences between the social innovation ecosystem and the entrepreneurial ecosystem. Thus, Isenberg's entrepreneurial ecosystem model is leveraged for the development of a novel social innovation ecosystem model

This study analyzes the most impactful critical success factors for corporate social responsibility projects in the context of Brazilian companies' to propose guidelines to better qualify new professionals and entrepreneurs in the face of sustainability challenges. Thirteen critical success factors were identified in selected literature sources and, through a survey with experienced professionals, it was possible to identify the six most relevant for Brazilian companies. Based on these results, three guidelines are proposed to better qualify professionals and entrepreneurs in the Brazilian context. These outcomes shed light on the needs that need to be met in entrepreneurial ecosystems to help entrepreneurs contribute to sustainability transitions

This study presents a quantitative vision of the study of crowdfunding through a bibliometric analysis of the most relevant publications. The main goal is to determine whether crowdfunding is really a subject of increasing interest, and to identify the most productive and influential sources of its scientific research. This study forms a foundation for new studies to delve deeper into this theme

By analyzing secondary data on 14 European countries, this study investigates how an entrepreneurial ecosystem can support entrepreneurs in creating entrepreneurial sustainable innovations (ESIs). The results show that ESIs are positively correlated with three elements of Isenberg's model of the entrepreneurial ecosystem (policy, finance, and infrastructural and administrative support), whereas two other elements of the model (culture and human capital) do not significantly influence ESIs. The country-level capabilities of the ESIs are also measured 
Table 5 (continued)

\begin{tabular}{ll}
\hline Authors and title & Contribution \\
\hline $\begin{array}{ll}\text { Moggi, Sara; Pierce, Paul; Bernardi, Nicole. From } \\
\text { sustainability to thrivability: an inductive }\end{array}$ & $\begin{array}{c}\text { This study proposes the thrivable entrepreneurial } \\
\text { ecosystem as the goal of entrepreneurial action } \\
\text { framework for entrepreneurial ecosystems }\end{array}$ \\
$\begin{array}{ll}\text { in the face of grand challenges. The proposed } \\
\text { thrivability approach to entrepreneurship aims to } \\
\text { create prosperity through ecosystemic resources } \\
\text { (re)generation and transformation based on }\end{array}$ \\
entrepreneurship-driven interorganizational \\
collaboration around common long-term \\
economic goals. The thrivability approach is \\
illustrated and further developed with an \\
in-depth qualitative analysis of an exemplary \\
case (the transformation of a local wine \\
ecosystem in Italy)
\end{tabular}

\section{Articles in this special issue}

The preceding sections highlight the dynamism of the research field focusing on the role of entrepreneurship in addressing grand challenges. The International Entrepreneurship and Management Journal is contributing to this viable and relevant debate and in 2019 launched the special issue "Grand Challenges and Entrepreneurship: Emerging Issues and Research Streams".

Overall, 23 papers were submitted. At the end of the review cycles, nine papers were accepted. Four of these studies contribute to the research streams that are synthesized in the left part of Fig. 3 and their contributions are synthesized in Table 4. The other five studies focus, from different standpoints, on the role of entrepreneurial ecosystems in pursuing sustainability and addressing the SDGs, thus contributing to research streams that are mapped in the central and right part of Fig. 3. The contributions of these five studies are synthesized in Table 5. Overall, we believe that these nine articles cover some of the most viable topics and approaches identified in our literature analyses. We hope that this special issue will make a significant contribution to the ongoing conversation on entrepreneurship and grand challenges.

Open Access This article is licensed under a Creative Commons Attribution 4.0 International License, which permits use, sharing, adaptation, distribution and reproduction in any medium or format, as long as you give appropriate credit to the original author(s) and the source, provide a link to the Creative Commons licence, and indicate if changes were made. The images or other third party material in this article are included in the article's Creative Commons licence, unless indicated otherwise in a credit line to the material. If material is not included in the article's Creative Commons licence and your intended use is not permitted by statutory regulation or exceeds the permitted use, you will need to obtain permission directly from the copyright holder. To view a copy of this licence, visit http://creativecommons.org/ licenses/by/4.0/.

\section{References}

Abdelkafi, N., \& Täuscher, K. (2016). Business Models for Sustainability From a System Dynamics Perspective. Organization and Environment, 29(1). https://doi.org/10.1177/1086026615592930 
Abele, S., Stasser, G., \& Chartier, C. (2010). Conflict and coordination in the provision of public goods: A conceptual analysis of continuous and step-level games. Personality and Social Psychology Review, 14(4), 385-401.

Adams, W. M., Brockington, D., Dyson, J., \& Vira, B. (2003). Managing Tragedies: Understanding Conflict over Common Pool Resources. Science, 302(5652), 1915-1916. https://doi.org/10.1126/science. 1087771

Albareda, L., \& Jose, A. (2020). Commons Organizing : Embedding Common Good and Institutions for Collective Action. Insights from Ethics and Economics. Journal of Business Ethics, Ostrom 1990. https://doi.org/10.1007/s10551-020-04580-8

Amis, J., Barney, J., Mahoney, J. T., \& Wang, H. (2020). From the Editor. Why we need a theory of stakeholder governance - and why this is a hard problem. Academy of Management Review, 45(3), 499-503.

Anand, A., Argade, P., Barkemeyer, R., \& Salignac, F. (2021). Trends and patterns in sustainable entrepreneurship research: A bibliometric review and research agenda. Journal of Business Venturing, 36(3). https://doi.org/10.1016/j.jbusvent.2021.106092

Ansari, S., Wijen, F., \& Gray, B. (2013). Constructing a climate change logic: An institutional perspective on the "tragedy of the commons." Organization Science, 24(4), 1014-1040. https://doi.org/10.1287/ orsc. 1120.0799

Apostolopoulos, N., Al-Dajani, H., Holt, D., Jones, P., \& Newbery, R. (2018). Entrepreneurship and the sustainable development goals. In Contemporary Issues in Entrepreneurship Research (Vol. 8). Emerald Group Publishing Limited. https://doi.org/10.1108/s2040-724620180000008005

Belz, F. M., \& Binder, J. K. (2017). Sustainable entrepreneurship: A convergent process model. Business Strategy and the Environment, 26(1), 1-17.

Berkes, F. (2009). Evolution of co-management: Role of knowledge generation, bridging organizations and social learning. Journal of Environmental Management, 90(5), 1692-1702. https://doi. org/10.1016/j.jenvman.2008.12.001

Bischoff, K., \& Volkmann, C. K. (2018). Stakeholder support for sustainable entrepreneurship - a framework of sustainable entrepreneurial ecosystems. International Journal of Entrepreneurial Venturing, 10(2), 172-201. https://doi.org/10.1504/IJEV.2018.092714

Bodin, Ö. (2017). Collaborative environmental governance: Achieving collective action in socialecological systems. Science, 357(6352). https://doi.org/10.1126/science.aan1114

Campbell, C., Pitt, L., Parent, M., \& Berthon, P. (2011). Understanding consumer con- versations around ads in a web 2.0 world. Journal of Advertising, 40(1), 87-102.

Cantino, V., Devalle, A., Cortese, D., Ricciardi, F., \& Longo, M. (2017). Place-based network organizations and embedded entrepreneurial learning: Emerging paths to sustainability. International Journal of Entrepreneurial Behavior and Research, 23(3), 504-523. https://doi.org/10.1108/ IJEBR-12-2015-0303

Cavallo, A., Ghezzi, A., \& Balocco, R. (2018). Entrepreneurial ecosystem research: present debates and future directions. In International Entrepreneurship and Management Journal (pp. 1-31). https://doi.org/10.1007/s11365-018-0526-3

Crecente, F., Sarabia, M., \& Del Val, M. T. (2021). Sustainable entrepreneurship in the 2030 horizon. Sustainability (switzerland), 13(2), 1-11. https://doi.org/10.3390/su13020909

de Clercq, D., \& Voronov, M. (2011). Sustainability in entrepreneurship: A tale of two logics. International Small Business Journal, 29(4), 322-344. https://doi.org/10.1177/0266242610372460

Dean, T. J., \& McMullen, J. S. (2007). Toward a theory of sustainable entrepreneurship: Reducing environmental degradation through entrepreneurial action. Journal of Business Venturing, 22(2), $50-76$.

Dietz, T., Ostrom, E., \& Stern, P. C. (2003). The Struggle to Govern the Commons. Science, 302(5652), 1907-1912. https://doi.org/10.1126/science.1091015

Doh, J. P., Tashman, P., \& Benischke, M. (2019). Adapting to grand environmental challenges through collective entrepreneurship. Academy of Management Perspectives, 33(4), 450-468. https://doi. org/10.5465/amp.2017.0056

Esteves, A. M., Genus, A., Henfrey, T., Penha-Lopes, G., \& East, M. (2021). Sustainable entrepreneurship and the Sustainable Development Goals: Community-led initiatives, the social solidarity economy and commons ecologies. Business Strategy and the Environment, 30(3), 1423-1435. https://doi.org/10.1002/bse.2706 
Fanning, A. L., O’Neill, D. W., \& Büchs, M. (2020). Provisioning systems for a good life within planetary boundaries. Global Environmental Change, 64(August 2019), 102135. https://doi.org/10. 1016/j.gloenvcha.2020.102135

Fellnhofer, K., Kraus, S., \& Bouncken, R. B. (2014). The Current state of research on sustainable entrepreneurship. International Journal of Business Research, 14(3), 163-172. https://doi.org/10.18374/ IJBR-14-3.11

Ferraro, F., Etzion, D., \& Gehman, J. (2015). Tackling Grand Challenges Pragmatically: Robust Action Revisited. Organization Studies, 36(3), 363-390. https://doi.org/10.1177/0170840614563742

Fjeldstad, O. D., Snow, C. C., Raymond, E. M., \& Lettl, C. (2012). The architecture of collaboration. Strategic Management Journal, 33(6), 734-750. https://doi.org/10.1002/smj

Foucrier, T., \& Wiek, A. (2019). A process-oriented framework of competencies for sustainability entrepreneurship. Sustainability (switzerland), 11(24), 1-18. https://doi.org/10.3390/su11247250

Frischmann, B. M., Marciano, A., \& Ramello, G. B. (2019). Retrospectives tragedy of the commons after 50 years. Journal of Economic Perspectives, 33(4), 211-228. https://doi.org/10.1257/jep.33.4.211

Genus, A. (2021). Sustainable entrepreneurship research in the 2020s: An introduction. Business Strategy and the Environment, 30(3), 1419-1422. https://doi.org/10.1002/bse.2705

George, G., Howard-Grenville, J., Joshi, A., \& Tihanyi, L. (2016). Understanding and tackling societal grand challenges through management research. Academy of Management Journal, 59(6), 18801895. https://doi.org/10.5465/amj.2016.4007

Gerard, G., Merrill, R. K., \& Schillebeeckx, S. J. D. D. (2020). Digital Sustainability and Entrepreneurship: How Digital Innovations Are Helping Tackle Climate Change and Sustainable Development. Entrepreneurship: Theory and Practice, 2018, 1-28. https://doi.org/10.1177/1042258719899425

Grimes, M. G., \& Vogus, T. J. (2021). Inconceivable! Possibilistic thinking and the sociocognitive underpinnings of entrepreneurial responses to grand challenges. Organization Theory, 2(2), 263178772110057. https://doi.org/10.1177/26317877211005780

Günzel-Jensen, F., Siebold, N., Kroeger, A., \& Korsgaard, S. (2020). Do the United Nations' Sustainable Development Goals matter for social entrepreneurial ventures? A bottom-up perspective. Journal of Business Venturing Insights, 13(January), e00162. https://doi.org/10.1016/j.jbvi.2020.e00162

Gupta, P., Chauhan, S., Paul, J., \& Jaiswal, M. P. (2020). Social entrepreneurship research: A review and future research agenda. Journal of Business Research, 113(October 2019), 209-229. https://doi.org/ 10.1016/j.jbusres.2020.03.032

Hardin, G. (1968). The Tragedy of the Commons. Science, 162(3859), 1243-1248.

Hess, C. (2008). Mapping the New Commons. Governing Shared Resources: Conneting Local Experience to Global Challenges. The Twelfth Biennial Conference of the International Association for the Study of the Commons, July, 1-76. https://doi.org/10.2139/ssrn.1356835

Higgins, J., Lesser, E., \& Bolman, S. (2014). From the Editors: Organizations with Purpose. Academy of Management Journal, 57(5), 1227-1234. http://search.ebscohost.com/login.aspx?direct=true\&db= bth\&AN=111482392\&site=bsi-live

Horne, J., Recker, M., Michelfelder, I., Jay, J., \& Kratzer, J. (2020). Exploring entrepreneurship related to the sustainable development goals - mapping new venture activities with semi-automated content analysis. Journal of Cleaner Production, 242, 118052. https://doi.org/10.1016/j.jclepro.2019. 118052

Isaksson, R. (2019). Creating a sense of urgency for sustainable development - Testing two system models. Journal of Cleaner Production, 227, 1173-1184. https://doi.org/10.1016/J.JCLEPRO. 2019.04.177

Jones, J., York, J. G., Vedula, S., Conger, M., \& Lenox, M. (2019). The Collective Construction of Green Building: Industry transitions toward environmentally beneficial practices. Academy of Management P, 33(4), 425-449.

Klapper, R. G., Upham, P., \& Blundel, R. K. (2021). Insider perspectives on growth: Implications for a nondichotomous understanding of 'sustainable' and conventional entrepreneurship. Business Strategy and the Environment, 30(3), 1481-1496. https://doi.org/10.1002/bse.2710

Kostakis, V., Latoufis, K., Liarokapis, M., \& Bauwens, M. (2018). The convergence of digital commons with local manufacturing from a degrowth perspective: Two illustrative cases. Journal of Cleaner Production, 197(September), 1684-1693. https://doi.org/10.1016/j.jclepro.2016.09.077

Kraus, S., Burtscher, J., Vallaster, C., \& Angerer, M. (2018). Sustainable entrepreneurship orientation: A reflection on status-quo research on factors facilitating responsible managerial practices. Sustainability (Switzerland), 10(2). https://doi.org/10.3390/su10020444 
Lachmann, L. M. (1976). From Mises to Shackle: An essay on Austrian economics and the kaleidic society. Journal of Economic Literature, 14(1), 54-62.

Littlewood, D., \& Holt, D. (2018). How social enterprises can contribute to the sustainable development goals (SDGs) - A conceptual framework. In Contemporary Issues in Entrepreneurship Research (Vol. 8, pp. 33-46). https://doi.org/10.1108/S2040-724620180000008007

Lüdeke-Freund, F. (2020). Sustainable entrepreneurship, innovation, and business models: Integrative framework and propositions for future research. Business Strategy and the Environment, 29(2), 665-681. https://doi.org/10.1002/bse.2396

Lumpkin, G. T., \& Bacq, S. (2019). Civic wealth creation: A new view of stakeholder engagement and societal impact. Academy of Management Perspectives, 33(4), 383-404. https://doi.org/10. 5465/amp.2017.0060

Markman, G. D., Russo, M., Lumpkin, G. T., Jennings, P. D. D., \& Mair, J. (2016). Entrepreneurship as a Platform for Pursuing Multiple Goals: A Special Issue on Sustainability, Ethics, and Entrepreneurship. Journal of Management Studies, 53(5), 673-694. https://doi.org/10.1111/joms. 12214

Markman, G. D., Waldron, T. L., Gianiodis, P. T., \& Espina, M. I. (2019). E pluribus unum: Impact entrepreneurship as a solution to grand challenges. Academy of Management Perspectives, 33(4), 371-382. https://doi.org/10.5465/amp.2019.0130

Martí, I. (2018). Transformational Business Models, Grand Challenges, and Social Impact. Journal of Business Ethics, 152(4), 965-976. https://doi.org/10.1007/s10551-018-3824-3

Masdeu Yélamos, G., Carty, C., Moynihan, Ú., \& ODwyer, B. (2019). The Universal Transformational Management Framework (UTMF): Facilitating entrepreneurship in and through sport to leave no one behind. Journal of Entrepreneurship and Public Policy, 8(1), 122-146. https://doi. org/10.1108/JEPP-D-18-00091

Meadows, D. H. (2009). Thinking in Systems. Sterling.

Mintrom, M., \& Thomas, M. (2018). Policy entrepreneurs and collaborative action: Pursuit of the sustainable development goals. International Journal of Entrepreneurial Venturing, 10(2), 153171. https://doi.org/10.1504/IJEV.2018.092710

Moon, C. J. (2018). Contributions to the sdgs through social and eco entrepreneurship: New mindsets for sustainable solutions. In Contemporary Issues in Entrepreneurship Research (Vol. 8, pp. 47-68). https://doi.org/10.1108/S2040-724620180000008008

Muñoz, P., \& Cohen, B. (2018). Sustainable Entrepreneurship Research: Taking Stock and looking ahead. Business Strategy and the Environment, 27(3), 300-322. https://doi.org/10.1002/bse.2000

Muñoz, P., Janssen, F., Nicolopoulou, K., \& Hockerts, K. (2018). Advancing sustainable entrepreneurship through substantive research. International Journal of Entrepreneurial Behavior and Research, 24(2), 322-332.

Nyström, M., Jouffray, J. B., Norström, A. V., Crona, B., Søgaard Jørgensen, P., Carpenter, S. R., Bodin, Ö., Galaz, V., \& Folke, C. (2019). Anatomy and resilience of the global production ecosystem. Nature, 575(7781), 98-108. https://doi.org/10.1038/s41586-019-1712-3

O'Shea, G., Farny, S., \& Hakala, H. (2021). The buzz before business: A design science study of a sustainable entrepreneurial ecosystem. Small Business Economics, 56(3), 1097-1120. https://doi. org/10.1007/s11187-019-00256-4

Ostrom, E., Burger, J., Field, C. B., Norgaard, R. B., \& Policansky, D. (1999). Revisiting the Commons: Local Lessons. Global Challenges. Science, 284(5412), 278-282. https://doi.org/10.1126/science. 284.5412.278

Ostrom, E. (1990). Governing the Commons: The evolution of institutions for collective action. Cambridge University Press.

Ostrom, E. (2009). A general framework for analyzing sustainability of social-ecological systems. Science, 325, 419-422.

Ostrom, E. (2010). Beyond Markets and States : Polycentric Governance of Complex Economic Systems. American Economic Review, 100(3), 641-672. https://doi.org/10.1257/aer.100.3.1

Pacheco, D. F., Dean, T. J., \& Payne, D. S. (2010). Escaping the green prison: Entrepreneurship and the creation of opportunities for sustainable development. Journal of Business Venturing, 25(5), 464480. https://doi.org/10.1016/j.jbusvent.2009.07.006

Peredo, A. M., \& Chrisman, J. J. (2006). Toward a theory of community-based enterprise. Academy of Management Review, 31(2), 309-328. https://doi.org/10.5465/AMR.2006.20208683 
Peredo, A. M., Haugh, H. M., Hudon, M., \& Meyer, C. (2020). Mapping Concepts and Issues in the Ethics of the Commons: Introduction to the Special Issue. Journal of Business Ethics, 0123456789. https://doi.org/10.1007/s10551-020-04584-4

Ricciardi F., Cantino, V., Rossignoli, C. (2020a). Organisational learning for the common good: An emerging model Knowledge Management Research \& Practice Practice, 1-14. https://doi.org/10. 1080/14778238.2019.1673676

Ricciardi, F., De Bernardi, P., \& Cantino, V. (2020). System dynamics modeling as a circular process : The smart commons approach to impact management. Technological Forecasting \& Social Change, 151(October 2019), 119799. https://doi.org/10.1016/j.techfore.2019.119799

Ridley-Duff, R., \& Bull, M. (2021). Common pool resource institutions: The rise of internet platforms in the social solidarity economy. Business Strategy and the Environment, 30(3), 1436-1453. https:// doi.org/10.1002/bse. 2707

Rossignoli, C., Ricciardi, F., \& Bonomi, S. (2018). Organizing for Commons-Enabling Decision-Making Under Conflicting Institutional Logics in Social Entrepreneurship. Group Decision and Negotiation, 27, 417-443. https://doi.org/10.1007/s10726-018-9564-Z

Sarango-Lalangui, P., Santos, J. L. S., \& Hormiga, E. (2018). The development of sustainable entrepreneurship research field. Sustainability (Switzerland), 10(6). https://doi.org/10.3390/su10062005

Sarasvathy, S. D., \& Ramesh, A. (2019). An effectual model of collective action for addressing sustainability challenges. Academy of Management Perspectives, 33(4), 405-424. https://doi.org/10.5465/ amp.2017.0090

Schaefer, K., Corner, P. D., \& Kearins, K. (2015). Social, Environmental and Sustainable Entrepreneurship Research: What Is Needed for Sustainability-as-Flourishing? Organization and Environment, 28(4), 394-413. https://doi.org/10.1177/1086026615621111

Schaltegger, S., \& Wagner, M. (2011). Sustainable entrepreneurship and sustainability innovation: Categories and interactions. Business Strategy and the Environment, 20(4), 222-237. https://doi.org/10. $1002 / \mathrm{bse} .682$

Schumpeter, J. A. (1934). The Theory of Economic Development. Harvard University Press.

Sigmund, K., De Silva, H., Traulsen, A., \& Hauert, C. (2010). Social learning promotes institutions for governing the commons. Nature, 466(7308), 861-863. https://doi.org/10.1038/nature09203

Soderstrom, S. B., \& Heinze, K. L. (2021). From Paradoxical Thinking to Practicing Sustainable Business: The Role of a Business Collective Organization in Supporting Entrepreneurs. Organization and Environment, 34(1), 74-98. https://doi.org/10.1177/1086026619885108

Standing, G. (2019). Plunder of the commons: A manifesto for sharing public wealth. Penguin.

Stubbs, W. (2017). Sustainable Entrepreneurship and B Corps. Business Strategy and the Environment, 26(3), 331-344. https://doi.org/10.1002/bse.1920

Sutter, C., Bruton, G. D., \& Chen, J. (2019). Entrepreneurship as a solution to extreme poverty: A review and future research directions. Journal of Business Venturing, 34(1), 197-214. https://doi.org/10. 1016/j.jbusvent.2018.06.003

Tiba, S., van Rijnsoever, F. J., \& Hekkert, M. P. (2020). The lighthouse effect: How successful entrepreneurs influence the sustainability-orientation of entrepreneurial ecosystems. Journal of Cleaner Production, 264, 121616. https://doi.org/10.1016/j.jclepro.2020.121616

United-Nations. (2015). Transforming our world: the 2030 agenda for sustainable development. Resolution adopted by the General Assembly on 25 September 2015. https://sustainabledevelopment.un. org/post2015/transformingourworld.

Venâncio, A., \& Pinto, I. (2020). Type of entrepreneurial activity and sustainable development goals. Sustainability (switzerland), 12(22), 1-25. https://doi.org/10.3390/su12229368

Venkataraman, S., Sarasvathy, S. D., Dew, N., \& Forster, W. R. (2012). Reflections on the 2010 AMR decade award: Whither the promise?Moving forward with entrepreneurship as a science of the artificial. Academy of Management Review, 37(1), 21-33.

Villar, E. B., \& Miralles, F. (2019). Sustainable entrepreneurship in response to grand challenges: What do we know and how do we move forward? DLSU Business and Economics Review, 28(3), 112120. https://www.scopus.com/inward/record.uri?eid=2-s2.0-85065402697\&partnerID=40\&md5= c8a31bd8b01872d4c147e464cf48bfd4

Vlasov, M., Bonnedahl, K. J., \& Vincze, Z. (2018). Entrepreneurship for resilience: Embeddedness in place and in trans-local grassroots networks. Journal of Enterprising Communities, 12(3), 374-394. https://doi.org/10.1108/JEC-12-2017-0100 
Volkmann, C., Fichter, K., Klofsten, M., \& Audretsch, D. B. (2021). Sustainable entrepreneurial ecosystems: An emerging field of research. Small Business Economics, 56(3), 1047-1055. https://doi.org/ 10.1007/s11187-019-00253-7

Wijen, F., \& Ansari, S. (2007a). Overcoming inaction through collective institutional entrepreneurship: Insights from regime theory. Organization Studies, 28, 1079-1100.

Wijen, F., \& Ansari, S. (2007b). Overcoming inaction through collective institutional entrepreneurship: Insights from regime theory. Organization Studies, 28(7), 1079-1100. https://doi.org/10.1177/ 0170840607078115

Wiklund, J., Wright, M., \& Zahra, S. A. (2019). Conquering Relevance: Entrepreneurship Research's Grand Challenge. Entrepreneurship: Theory and Practice, 43(3), 419-436. https://doi.org/10.1177/ 1042258718807478

Wilden, R., Devinney, T. M., \& Dowling, G. R. (2016). The Architecture of Dynamic Capability Research Identifying the Building Blocks of a Configurational Approach. Academy of Management Annals, 10(1), 997-1076. https://doi.org/10.5465/19416520.2016.1161966

Publisher's Note Springer Nature remains neutral with regard to jurisdictional claims in published maps and institutional affiliations.

\section{Authors and Affiliations}

\section{Francesca Ricciardi ${ }^{1}$. Cecilia Rossignoli ${ }^{2} \cdot$ Alessandro Zardini $^{2}$}

1 University of Turin, Turin, Italy

2 University of Verona, Verona, Italy 